NBER WORKING PAPER SERIES

THE EVOLUTION OF BANK SUPERVISION:

EVIDENCE FROM U.S. STATES

\author{
Kris James Mitchener \\ Matthew Jaremski \\ Working Paper 20603 \\ http://www.nber.org/papers/w20603
NATIONAL BUREAU OF ECONOMIC RESEARCH
1050 Massachusetts Avenue
Cambridge, MA 02138
October 2014

We thank Jessica Hardwick, Lea Halloway, and Amanda Razon for invaluable research assistance and Mark Carlson, David Wheelock, Charles Calomiris, and Paul Rhode for comments and suggestions. The views expressed herein are those of the authors and do not necessarily reflect the views of the National Bureau of Economic Research.

NBER working papers are circulated for discussion and comment purposes. They have not been peerreviewed or been subject to the review by the NBER Board of Directors that accompanies official NBER publications.

(C) 2014 by Kris James Mitchener and Matthew Jaremski. All rights reserved. Short sections of text, not to exceed two paragraphs, may be quoted without explicit permission provided that full credit, including $\odot$ notice, is given to the source. 
The Evolution of Bank Supervision: Evidence from U.S. States

Kris James Mitchener and Matthew Jaremski

NBER Working Paper No. 20603

October 2014

JEL No. E44,G28,N11

\title{
ABSTRACT
}

We use a novel data set spanning 1820-1910 to examine the origins of bank supervision and assess factors leading to the creation of formal bank supervision across U.S. states. We show that it took more than a century for the widespread adoption of independent supervisory institutions tasked with maintaining the safety and soundness of banks. State legislatures initially pursued cheaper regulatory alternatives, such as double liability laws; however, banking distress at the state level as well as the structural shift from note-issuing to deposit-taking commercial banks and competition with national banks propelled policymakers to adopt costly and permanent supervisory institutions.

\author{
Kris James Mitchener \\ Department of Economics \\ Leavey School of Business \\ Santa Clara University \\ Santa Clara, CA 95053 \\ and NBER \\ kmitchener@scu.edu \\ Matthew Jaremski \\ Colgate University \\ Department of Economics \\ 13 Oak Drive \\ Hamilton, NY 13346 \\ and NBER \\ mjaremski@colgate.edu
}




\section{The Evolution of Bank Supervision: Evidence from U.S. States}

It is surprising how little is actually known about when and why formal bank supervisory institutions came into existence. For example, existing research on their early evolution in the United States simply summarizes the environment for particular years (e.g., Weldon 1910) or presents a limited number of case studies (e.g., Gruchy 1937). More recent studies have examined supervision in later periods (Agarwal et al. 2011; Mitchener 2005, 2007; White 2011), but they have not attempted to provide a long-term quantitative assessment of the evolution of bank supervisory institutions. ${ }^{1}$ We aim to fill this lacuna by analyzing the factors that led to the creation of formal bank supervisory institutions in the United States at the state level, where such institutions are defined as government agencies established specifically for the purpose of supervising banks. We examine their evolution in light of theory as well as modern policy objectives, such as the reduction of systemic risk and the monitoring of bank balance sheets and management behavior.

The federalist structure of the United States implies that powers, such as the chartering of commercial banks, primarily reside with individual states. Supervision of banks chartered by states naturally followed from this delegation of powers, and meant that bank supervision initially developed at this jurisdictional level. We thus focus on when and why U.S. states established banking departments designed to both charter and supervise state financial institutions. We trace their evolution from the early years of the republic through the beginning of the twentieth century - a critical period that laid down the foundations of the bank supervisory system observed today. To do so, we assemble a unique data set spanning 1820-1910 from archival and census records that provides information on the date of adoption of formal institutions as well as on state-specific factors influencing that decision. Using these data and additional information on supervisory characteristics, we also examine whether states made progressive improvements to the quality of their supervisory institutions. Since implementation

\footnotetext{
${ }^{1}$ Another notable recent contribution is Grossman (2010), which describes the evolution of the banking industry and discusses the role central banks have played in bank supervision (with extended case studies on Sweden, England, and the United States). Our analysis is complementary in that it analyzes the evolution of bank supervision prior to central banking and formally measures its determinants.
} 
dates and supervisory characteristics varied considerably across states, we are able to exploit both the cross-state and time differences to identify factors that drove the adoption of state bank supervision.

It took more than 100 years to fully develop formal supervisory institutions as well as what policymakers today would consider as modern supervisory priorities. ${ }^{2}$ Consistent with Rajan's (2009) view that financial regulation has been procyclical, we find that formal supervisory institutions (i.e., state banking departments) rose from the ashes of banking crises. Six states created government banking agencies immediately after the Panic of 1837, six states put them in place after the Baring Crisis of 1890 and Banking Panic of 1893, and 17 made changes after the Panic of 1907. No other interval had as many new departments established. The pattern indicates that formal bank supervision was likely a response to bank failures: the high sunk costs of establishing formal bank supervisory institutions likely delayed states from preemptively installing them.

The introduction of the National Banking Act and taxes on state bank notes in the 1860s also appears to have shaped the development of modern supervisory institutions and priorities. Commercial banks shifted the composition of their liabilities from notes to deposits, simultaneously drawing more individuals (and potential voters) into the banking sector and increasing the potential for systemic bank runs. ${ }^{3}$ The shift also potentially allowed banks to increase their loan portfolios relative to bond purchases thus more closely tying economic activity to bank health (Calomiris and Mason, 2008). Our econometric results suggest that state legislatures refocused their attention on the safety of depositors and installed relatively more costly state banking departments. As deposit taking grew in importance relative to note issuance, supervision shifted more purposefully toward maintaining the safety and soundness of banking systems.

\footnotetext{
${ }^{2}$ Some of the delayed adoption is an artifact of new states that were created late in the period, but there were still many older states (e.g., Indiana, North Carolina, Pennsylvania, and South Carolina) that did not install formal supervision until after 1890 .

${ }^{3}$ While note holders were exposed to bank failure, notes had to be fully backed by collateral and losses were generally low. Issuance of greenbacks and silver-backed money during the postbellum period also limited the amount of bank notes that individuals would need to hold in order to carry out transactions.
} 
States also reacted to the threat of national banking itself. Rather than allowing banks to charter under the Office of the Comptroller of the Currency, states offered an alternative regulatory and supervisory environment by establishing formal institutions. The entry rate of national banks is positively correlated with the adoption of state banking departments and of publishing regular banking reports. Therefore, unlike other studies that find the competition between banking systems led to regulatory laxity, the competition might also have been beneficial.

By the beginning of the twentieth century and prior to the founding of the Federal Reserve System, most states had established separate regulatory agencies charged with bank supervision and required banks to regularly submit balance sheet information. Our empirical evidence further indicates that states that moved earlier to create an independent banking authority devoted more resources toward supervision. Early adopters were more likely to publish highly detailed and regular bank reports, spend more on supervision expenses, and carry out more examinations per bank. Some of these states had also given their examiners the power to shut down banks that were deemed unsafe. Because enforcement problems, compliance, and competition with federal regulatory agencies persisted long after the founding of the Federal Reserve System, these quality differentials may have had lasting implications for systemic stability.

\section{Theoretical Arguments for Supervision}

In its broadest form, prudential supervision can be defined as government regulation and monitoring of the banking system to ensure its safety and soundness. Prudential supervision often works in conjunction with legislated rules and requirements. For example, supervisory authorities might deny charters to banks that do not have sufficient paid-in capital, monitor banks

to ensure compliance with capital or reserve requirements or disclosure rules, or ensure speedy resolutions to failed institutions. While much has been written about branching restrictions, double liability laws, and deposit insurance in the U.S., considerably less is known about how and why supervision evolved. 
Public and private interest theories of regulation suggest at least three explanations for the special treatment of banks: externalities, efficiency, and vested interests. When large numbers of banks fail they often impose external costs on the economy, reducing lending and aggregate investment. Moreover, as banks fail and disintermediation occurs, the costs of credit can rise for firms due to the loss in information about the quality of investment projects (Bernanke 1983). Since commercial banks are conduits through which the money supply changes, a large number of failures can also impact the macroeconomy by altering the money supply (Friedman and Schwartz 1963). Prudential regulation and supervision could therefore potentially reduce the incidence of failures and "contagious runs," and limit macroeconomic externalities.

A second public-interest argument for regulating and supervising banks has to do with the efficient transfer of savings from lenders to borrowers. As in other industries, market structure can affect the price and provision of services. In banking, this translates to lending rates and risk-return tradeoffs that are influenced by the competitive structure of the industry. While government policies often limit entry and increase the monopoly power of existing banks by making chartering costly (imposing requirements on paid-in capital or controlling who can receive licenses to operate), formal supervision could arise to ensure product and price competition and to enforce legal restrictions on bank activity. ${ }^{4}$ Absent intervention, market structure in banking could evolve in a way that leads to an inefficient or suboptimal allocation of capital and services, either geographically or in terms of sectoral allocation, resulting in slower economic growth. ${ }^{5}$

Efficiency theory further suggests that bank supervision may enhance welfare given costly state verification (Townsend 1979), monitoring costs, the opacity of bank decision making (Chen 2001, Meh and Moran 2010), and incentive problems. When present and without monitoring, managers may take on more risk than what is optimal from a depositors' perspective

\footnotetext{
${ }^{4}$ In the historical context of the United States, Davis (1965), Sylla (1969), James (1976), and Sullivan (2009) argue that the high capital requirements of national banks and taxes on state bank notes after 1865 enabled geographicallysegmented unit banks to obtain considerable monopoly power.

${ }^{5}$ The special status often conferred to banks is sometimes confounded with a government's desire to extract seigniorage through monopoly note issuance. While governments may desire to have control over note issuance to derive rents, it is not clear that supervision of banks is necessary to achieve this objective.
} 
(i.e., moral hazard). Asymmetric information may be lessened through government activities aimed at transparency, but supervision can achieve the same purpose by providing independent collaboration of accounting information and by checking for management fraud. It is certainly possible that banks could monitor their own risk. For example, managers (directors) could also be owners, aligning incentives and limiting risk taking. Alternatively, managers' contracts could be structured such that they are incentive compatible, in turn limiting risk taking and rendering government policies aimed at reducing risk potentially redundant. ${ }^{6}$

Demandable deposits could also potentially operate like incentive compatible contracts. A bank offers to pay a fixed return on deposits, which can be withdrawn at any time, in exchange for use of deposits. If depositors doubt the safety of their bank, they have the ability to run the bank. $^{7}$ The possibility of bank runs may act to discipline bank managers such that they hold less risky portfolios (Calomiris and Kahn 1991). When monitoring and information releases are imperfect, however, managers may still invest in risky assets and depositors may still rationally start bank runs. If runs become "contagious," they can potentially result in costly spillovers to the real economy. The possibility of "contagious" and costly bank runs provides a theoretical justification for supervision and/or regulation of banks: governments can commit resources to develop technologies that monitor risk taking. ${ }^{8}$

Formal rules or regulations on bank behavior are another mechanism that can be used to incentivize managers to operate in ways that are incentive compatible with depositors. For example, contingent liability laws make bank stockholders liable for losses up to the amount of their stock. Grossman (2001) shows that double liability pushed banks to reduce their risk, but that it did not guarantee systemic stability. Reserve requirements on deposits and minimum capital requirements have also been enacted to rein in bank risk taking.

\footnotetext{
${ }^{6}$ If such contracts can be created, then regulation of risk taking may be unnecessary since losses would accrue to equity and debtholders just like for firms in other sectors.

${ }^{7}$ Theorists have shown that it is rational for depositors to run on fractional reserve banks (Diamond and Dybvig 1983).

${ }^{8}$ It is possible that banks could act jointly and come up with collective mechanisms that would prevent spillovers to each other or to the economy, but in practice such practices have been few and far between as a result of coordination problems. Calomiris and Schweikart (1991) note that several states responded to the Panic of 1857 by developing coordination technologies.
} 
Public choice theories of regulation provide a third explanation for supervision, suggesting that it might evolve in response to the needs of the banks they oversee. Stigler (1971) theorized that regulation principally serves to redistribute economic resources from those with less political power to those with more. ${ }^{9}$ For example, banks may lobby for restrictions on branching or chartering and then use government agencies, such as bank supervisory departments, to limit entry. Public interest objectives thus can be compromised by the agendas of well-organized bankers, customers, or political constituencies. Consequently, even without spillovers or efficiency considerations, regulation may still be compatible with the self-interest and profit maximizing motives of banks.

\section{Institutional Development of Bank Supervision in the U.S.}

Although theory can provide some guidance as to why states may have created bank supervisory institutions, state legislatures' perceptions about the public need for supervision appear to have been shaped by the changing economic environment, including the growth of the nation, innovations in the banking industry, and the incidence of costly and unevenly distributed financial panics. Indeed, as we document here and in the empirical exercises that follow, it would be difficult for a single theory to account for the decision to adopt formal supervisory institutions: rather, the objective of policymakers seem to have shifted over time. Hence, in this section, we describe the evolution of state banking departments over three eras, highlighting key factors that may have influenced policymakers' decision-making to create permanent state banking departments. The first period covers the nation's early history, when banks received special charters from state legislatures to operate. The second period corresponds to the Free Banking Era - from the 1830s through the Panic of 1857 and the large number of bank closures during the early years of the Civil War. The last period covers the National Banking Era, 18631913, which includes the rise of dual banking, the shift to deposit-taking commercial banks, and the Panic of $1907 .{ }^{10}$

\footnotetext{
${ }^{9}$ See also Posner (1971, 1974) and Peltzman (1976).

${ }^{10}$ Grossman (2010) uses a similar periodization to study the evolution of banking and various prudential regulations (e.g., double liability and minimum capital requirements).
} 


\section{A. Special Bank Charters and the Young Republic}

Commercial banking emerged slowly during the first decades of the 19th century, a period when private banks and moneylenders featured prominently. In part, the growth in banking was hindered by the chartering process. Individuals wanting to create a bank had to seek legislative approval at the state level. The use of special acts of incorporation to charter banks was a practice inherited from Europe. American legislators, however, viewed their authority to bring banks into existence with some trepidation, fearing that charters effectively granted monopolies that were concentrated in a "moneyed elite." Because states were banned from issuing their own currency, some politicians also worried about concentrating banks' unique power to create money through note issuance in the hands of a few. ${ }^{11}$ Special charters balanced two objectives: permitting banks to exist but providing more control over banking than a fixed set of standards.

The chartering process was tedious and requests were often denied by state legislatures. In order to obtain a charter, banks often had to agree to purchase government debt or make loans to the state (Bodenhorn 2003). ${ }^{12}$ Special bank charters were also susceptible to influence peddling, and many histories of this period describe a process whereby charters were handed out only to those that were politically connected. For example, as one banking historian describes, "It had long been difficult to get new bank charters in New York...And whenever a new one was decided on...opportunities were afforded the public to purchase stock - provided of course that most of the stock went into the possession of Democrats" (Hammond 1957, 574). Centralized banking was ironically enhanced by the special chartering process. Since banks needed special government privilege to operate, the number of banks grew slowly, mostly in urban areas, and banks had considerable monopoly power.

Bank supervision sprouted its first roots in response to these special charters, and with the general concern of giving banks the right to exist and issue notes. ${ }^{13} \mathrm{~A}$ few legislatures attempted

\footnotetext{
${ }^{11}$ Although they feature less prominently in the early discussions of bank chartering, some legislatures expressed concern that the issuance of "bad notes" would lead to a faulty money supply or that excessive note issuance could lead to inflation.

${ }^{12}$ This was another common European practice. Bodenhorn (2003) and Hammond (1957) provide detailed descriptions of the evolution of bank charters and the politics surrounding chartering during the antebellum period. ${ }^{13}$ Some states placed limitations on note issuance or prohibited dealings in certain types of securities. These types of provisions were often vague and enforcement was virtually non-existent.
} 
to require officials to obtain simple reports of condition on banks they had chartered or put into individual banks' charters the right to inspect them by forming special committees. However, these requirements had little bite and were often avoided. When reports were requested, it was easy to hide the true state of a bank's condition. Virginia's problems are indicative of this early era of bank supervision. In 1817, residents of Lynchburg accused Farmers' Bank of Virginia of discriminating in its lending practices, including lending excessively to insiders (directors) and real estate agents. In response, the legislature appointed a committee to examine the bank's practices, but the bank's directors had no incentive to cooperate with the committee: there was no legal means to force compliance with requests for information or changes in conduct (Gruchy 1937).

In spite of these shortcomings, incremental improvements took place in the first three decades of the $19^{\text {th }}$ century. Massachusetts passed a law in 1803 requiring periodic statements by banks; the law specified which items were to be included and authorized the assessment of fines when reports were not submitted. In 1813, the governor set up a system of three bank commissioners to enforce charter regulations, including minimum paid-in capital, but their examinations could not be described as comprehensive by any means (Gruchy 1937).

New York also moved relatively early to improve bank supervision. The New York Safety Fund, set up in 1829, established a mutual insurance system that guaranteed the liabilities of failed banks. ${ }^{14}$ The fund authorized three bank commissioners to examine member banks on a quarterly basis and determine if they were solvent. This public-private partnership also authorized any three banks to call for the examination of any other bank within the system. ${ }^{15}$ Despite giving the bank commissioners the power to supervise member banks, they had no legal basis to shut down banks unless they were in violation of a particular section of state banking law. The fund eventually had to be bailed out through state borrowing after the Panic of 1839, making it any early example of socialized risk in the American banking system. ${ }^{16}$

\footnotetext{
${ }^{14}$ It is helpful to note that the insurance was only intended to cover bank notes, and it was only through loose wording that some depositors were paid out. During the collapse of the system, New York properly defined the language to make sure that no additional depositors were repaid.

${ }^{15}$ The fund, however, did not properly incentivize its member to monitor each other as failures were borne by the fund and not individual banks (Weber 2011).

${ }^{16}$ Safety Funds were also started in Vermont in 1831 and Michigan in 1836, but they suffered from similar problems.
} 
A group of banks in Indiana also set up a self-insurance system to limit risk taking in 1834. Under this system, state banks in Indiana were independent but were mutually responsible for each other's liabilities. A board of directors, composed primarily of the individual bank presidents, was created to oversee the integrity of all the banks in the system. This structure encouraged banks to monitor each other's portfolios in order to prevent default while allowing each bank a large degree of autonomy (Weber 2011). As a result, no member bank in Indiana failed during the Panics of 1837 and 1839. Eventually groups of banks in Ohio (1845) and Iowa (1858) set up similar mutual guarantee systems.

Archival evidence from the era of the early republic shows that formal bank supervisory institutions were only present in Massachusetts and New York before 1830, despite nearly 313 banks operating across the other 23 states. Legislative records at both the state and national level also suggest little impetus for more formalized bank supervision. If anything, the 1830s ushered in the Jacksonian Era of Free Banking and a move toward less government involvement in banking at both the national and state level.

\section{B. The Free Banking Era: Unleashing the Genie from the Bottle}

Bank creation through special legislative chartering does not appear to have quenched the nation's thirst for capital. Beginning in the 1830s, 18 states passed general bank incorporation acts permitting groups of individuals to form banks without legislative approval. ${ }^{17}$ Free banking laws were particularly prevalent in the Midwest, but many states in the Northeast also passed versions. These laws specified a well-defined set of capital, reserve, and note-issuance requirements. While these particular requirements differed by jurisdiction, all free banks, regardless of the state in which they were chartered, were required to fully back their note issues with government bonds or other specified assets. ${ }^{18}$

\footnotetext{
${ }^{17}$ Rolnick and Weber (1983, p.1082) dates the passage of free banking laws as follows: Michigan 1837 (repealed 1839) and 1857; Georgia 1838; New York 1838; Alabama 1849; New Jersey 1850; Illinois 1851; Massachusetts 1851; Ohio 1851; Vermont 1851; Connecticut 1852; Indiana 1852; Tennessee 1852; Wisconsin 1852; Florida 1853; Louisiana 1853; Iowa 1858; Minnesota 1858; Pennsylvania 1860. Kentucky, Missouri, and Virginia are generally not considered free banking states as their general incorporation law differed from the rest.

${ }^{18}$ The intent was that notes should be "riskless" since the bank's collateral in the form of bonds should have been sufficient to cover the note issuance. There was also no risk of the bank absconding with the collateral as it was held by state officials.
} 
Free banking reduced entry costs and hence led to a tremendous growth in the number of state commercial banks. ${ }^{19}$ Despite the financial panics of 1837,1839 , and 1857 , the commercial banks in the U.S. increased from just over 765 banks in 1836 to more than 1,600 in 1860 . Consistent with the laissez faire nature of the laws, free banking states generally did not create costly stand-alone agencies to monitor the behavior of all the newly created banks. Instead, the laws contained simple rules requiring notes to be fully backed with collateral that was then surrendered to a state official in the hope that these requirements would prevent losses. While noteholders could run on banks, repayment concerns only arose when there were dramatic movements in the bond market or economic shocks that would have affected all banks in a given state. Idiosyncratic bank risk was not the primary concern of policymakers during this period. During the discussion of free banking in Indiana's Constitutional Convention of 1850, it was argued that "the state should have no more interest in banks than to protect the billholder. All else must be left to the exigencies of commerce." (Esarey, 1912, pp. 272-273) Legislatures were more likely to increase backing requirements than watch over bank activities, and at most, free banks were required to publish unaudited balance sheets a few times a year. Hence with little government attention directed toward supervision, depositors, noteholders, and creditors had to rely on private monitoring and the limited published data of banks to obtain information about bank behavior.

Free banking nevertheless raised several concerns for state policymakers, foremost of which was the issuance of notes by free banks. The legislation placed few, if any, restrictions on the size of note issuance, continuing a trend that had been started in the era of special bank chartering. ${ }^{20}$ By 1860 , thousands of types of bank notes circulated, constituting two-thirds of the money supply (Temin 1969, Table 5.2). The vast array of notes represented a potential risk to state banking systems since note issuance was not fundamentally limited and since mechanisms to induce banks to issue them prudently were largely lacking in state laws.

During the Free Banking Era, state banking proved to be susceptible to bond market fluctuations. By 1863, nearly two-thirds of all free banks and about a third of all legislatively charter banks had closed their doors. Due to the requirement that notes be fully backed, losses to

\footnotetext{
${ }^{19}$ For instance, 46 free banks were chartered in four years after free banking was established in Wisconsin.

${ }^{20}$ Banks received interest on their bond collateral and thus had little incentive to rein in their issuance.
} 
depositors and noteholders were generally minor outside of panics and a few states (King 1983). ${ }^{21}$ Scholars point to insufficient portfolio diversification and lack of proper supervision as reasons for these failures (Jaremski 2010). Rockoff (1974) and Rolnick and Weber (1984), for instance, highlight how Indiana state officials did not accurately price collateral bonds, and how Minnesota's law allowed risky revenue bonds to be used as collateral. In response, 15 states established separate banking authorities (generally called state bank commissioners) between 1830 and 1863. Similar to the New York Safety Fund, however, most authorities had little power to take action against banks that were in danger of becoming insolvent; they primarily focused on determining if de novo banks were in compliance with capital and note requirements. Moreover, at this point in time, very few states had developed banking departments that devoted resources to regular and periodic examinations of balance sheets and the monitoring of risk taking.

Banking panics, in particular, seem to have played a central role in the creation of these banking departments. Of the 15 states that installed supervision between 1830 and 1863, six states created formal supervisory institutions in the three years following the Banking Panic of 1837, and two of the hardest hit states of the Panic of 1857, Iowa and Missouri, set them up within two years of experiencing bank failures. The number of large and publicized bank closures stirred up fears of instability. Politicians seized upon these failures, using banking reform as a platform for gaining electoral support. ${ }^{22}$

Even New York and Massachusetts upgraded their institutions in response to the instability of the era. After the suspension or failure of 32 banks, Massachusetts strengthened its board of bank commissioners in 1838, requiring it to conduct annual examinations of all banks in addition to any special examinations requested by the legislature. The state supreme court also empowered the commissioners to force any bank to cease unsound practices. This provision provided the first basis for a state's supervisory authority to take action before a bank became

\footnotetext{
${ }^{21}$ About a third of all free banks and a fifth of all charter banks left behind some noteholder losses. Antebellum banks also issued more short-term debt and made far fewer long-term commercial loans and investments than today's banks; hence liquidity mismatch was less of a problem. They also tended to make many loans to insiders and members of the board of directors (at least in the Northeast), thus lessening the information asymmetry problem and reducing losses (Lamoreaux 1986, 1994).

${ }^{22}$ For instance, the architect of the National Banking Act, Salmon Chase, railed against the improper behavior of state banks while he was governor of Ohio (Davis, 1910).
} 
insolvent, and eventually became a universal feature of state bank regulation. In 1851, the state passed a free banking law and, in contrast to some other states, simultaneously enabled stockholders or creditors to request an examination of any bank in the state.

In response to the 1837 and 1839 Panics, in 1841 New York passed a law in 1841 requiring all bank notes to be backed by its state bonds or Federal bonds; in 1843, it also abolished its banking commissioners after the failure of the Safety Fund. In 1851, New York then transferred authority from the State Comptroller to a newly, independent banking department. The superintendent of this department was authorized to hire as many examiners as "necessary," had the authority to require quarterly reporting of balance sheets from all banks, and (in 1853) gained the power to solicit weekly statements of condition for all banks. ${ }^{23}$

\section{The Era of the Dual Banking: Bottling the Genie}

The Panic of 1857, the Civil War, and a series of banking failures in the early 1860s ushered in dramatic changes to the American banking system. The National Banking Acts of 1863 and 1864 established national banks - a new type of commercial bank that was federally chartered by the Office Comptroller of the Currency and competed with state chartered banks. The Act adopted free banking's process of incorporation, but made that conditional on higher capital, note, and reserve requirements than many state laws. ${ }^{24}$ Borrowing extensively from the supervisory systems of New York, Massachusetts, and Louisiana, the Office of the Comptroller of the Currency (OCC) also extended government's role in supervising banks. It required the commercial banks it chartered (national banks) to file reports of condition five times a year, and implemented a system of regular bank examinations. OCC examiners were charged with looking at the balance sheets as well as the quality of management and loans of national banks. While the OCC had the ability to prohibit payments of dividends and compel write-downs of capital, it still did not have the authority to force banks that were nearing insolvency to alter their behavior

\footnotetext{
${ }^{23}$ These features were later embraced by the Comptroller of Currency's office, the regulatory agency authorized to oversee national banks beginning in the 1860s (Gruchy 1937).

${ }^{24}$ First, the Acts avoided the attachment of note issuance to risky state debt by requiring the use of U.S. Treasury bonds to back $90 \%$ of their value. Second, they prevented the creation of rural banks by increasing minimum capital requirements. Third, the Acts avoided land speculation by prohibiting loans secured by real estate. Finally, they increased reserves on notes and required them on deposits as well.
} 
(Bolles 1888; Robertson 1968). It only had the authority to force a suspension if the bank had defaulted and failed to redeem its bank notes. ${ }^{25}$

Competition from national banks as well as a tax placed on state bank notes fundamentally altered the balance sheets of state banks. Liabilities shifted from notes to deposits. Figure 1 shows that deposits in the antebellum period were a smaller and relatively constant portion of liabilities than bank notes through the late $1850 \mathrm{~s}$, but deposits quickly increased relative to circulation after the state of the Civil War. The rise in deposits is often attributed to state banks gradually introducing demand deposits and checking accounts as a way of competing with national banks, but national banks also seized upon the benefits of deposits. By the end of 1900, bank notes made up less than $10 \%$ of all liabilities. The shift in the U.S. banking system to the widespread use of demand deposits exposed banks to greater liquidity risk and depositor runs, as witnessed by the banking Panics of 1873, 1893, and 1907, where liquidity seems to have played a role (Sprague 1910).

In response to the rise of demandable deposits, state policymakers seem to have begun to shift their focus toward ensuring bank safety and making improvements in supervisory standards in order to protect depositors and improve solvency. However, this shift began slowly, with significantly cheaper alternatives like double liability laws being installed first.

Double liability maintained that directors, chief executive officers, chief financial officers, and stockholders of banks would have to pay up to twice the par value of their shares in the event of bank failure. With more at stake, bank owner-managers may have taken less risk. States appear to have adopted this earlier than formal supervision (with 32 states installing double liability prior to creating a separate banking department) as an early attempt to mitigate bank risk taking. ${ }^{26}$ Figure 2 shows that most states in the Midwest and Northeast had passed a double liability law before 1870, and potentially in response to the National Banking Acts' requirements, many more passed one during the 1870s and 1880s. By 1890, 27 states had enacted double liability.

\footnotetext{
${ }^{25}$ White (2009) provides much more detail on supervision under the OCC and offers some comparison with state supervision.

${ }^{26}$ Only 7 states installed double liability after a separate banking authority was created (GA, MI, MS, NH, NV, NY, OR). The average state installed double liability almost 15 years before the authority.
} 
In contrast to double liability, the creation of independent state banking departments saw little development between 1863 and 1890. Only California installed bank commissioners during this 27-year period, bringing the number of states that had a separate department to 18 in 1890 (Figure 3). The next two decades, however, saw a flurry of activity, such that by 1914, only Arizona, Delaware, and Indiana were without an independent banking authority. Once again, banking crises seem to have been an agent for change, bringing the shortcomings of the states' supervisory systems to the forefront. Six states installed formal supervisory institutions within four years of the Baring Crisis of 1890 and the (banking) Panic of 1893; 17 more states established formal supervisory institutions between 1907 and 1914.

Existing state banking departments also responded to the Panic of 1907. For instance, in 1908 New York granted its state banking department the right to restrict chartering by requiring that banks receive charters only if "public convenience and advantage" necessitated a new financial institution. Several other states passed similar legislation or began to more strongly enforce restrictions on the chartering of new banks.

Some legislatures also augmented their existing supervisory institutions with reserve requirements and deposit insurance after panics. 35 states installed reserve requirements on deposits between 1889 and 1914, and deposits insurance was not tried again until after 1907. That said, only nine states installed reserve requirements on deposits before establishing permanent state banking departments, and only Indiana established deposit insurance prior to installing permanent bank supervisory institutions. Thus, unlike double liability, deposit insurance and reserve requirements lagged bank supervision.

By the beginning of the twentieth century, the actions of state banking authorities had been affirmed by the Supreme Court of the United States. In a 1911 decision, the Supreme Court ruled: "It has been held, we do not doubt rightly, that inspections may be required and the cost thrown on the bank." (Noble State Bank v. Haskell, 219 U.S. 104. January 3, 1911). Therefore, groundwork had been laid for supervision in the public interest prior to the creation of the Federal Reserve System.

\section{The Determinants of State Bank Supervision}


We now turn to assessing the factors that drove the adoption of formal bank supervision, using the historical evidence presented in Section II as well as economic theory to guide the selection of determinants. Drawing on a wide variety of historical records, including state constitutions, state banking reports, and survey data from state banking departments described in the data appendix, we obtained the year in which each state first established an independent banking authority (e.g. Office of the Bank Examiner, Bank Commissioner, or state banking department), our measure of formal supervision. To explain the timing of adoption, we estimate Cox proportional hazard models where observations are by state and by decade. ${ }^{27}$ The panel is updated each decade, such that states without banks or areas that were still territories are excluded from the sample until those conditions are met. The dependent variable is coded as either a zero in a decade where the state had not established an independent banking department for any of the years of that decade or a one if the department came into existence during the decade. ${ }^{28}$ The coefficients in the hazard model provide the relative effect on the probability of adopting supervision, but unlike probit or logit models, the estimation procedure allows us to account for differential state entry dates and the unbalanced nature of our panel by controlling for the date at which statehood was obtained. In our tables of results, a positive coefficient implies a particular covariate increases the probability of adoption whereas a negative coefficient implies it decreases the probability of creating a state banking department.

We include a large set of conditioning variables that may have influenced the legislative decision on when to create formal state bank supervision. ${ }^{29}$ Our first independent variable is the rate of bank entry in a given decade relative to the number of banks at the beginning of the decade. Public choice theory suggests that existing banks would lobby state legislators to impede

\footnotetext{
${ }^{27}$ Because demographic and economic data on states are only available every 10 years, we conduct the model at the decade level rather than exclude potentially important determinants. While hazard models are often used for continuous data and the proportionality assumption might miss some of the effect of the explanatory variables, the results reported in the paper are robust to using discrete choice models as well as other types of survival models. ${ }^{28}$ In order to form a complete panel of states, we disaggregate states such as West Virginia and Virginia and South and North Dakota for the whole period.

${ }^{29}$ Many of these same factors have been used by Grossman $(2001,2007)$ and others to study the political economy of prudential regulation such as double liability.
} 
the development of banking systems to protect their rents. ${ }^{30}$ A negatively-signed coefficient would be consistent with existing banks lobbying policymakers to promote their own interests, perhaps to protect themselves from competition or to forestall the creation of institutions requiring greater disclosure of profits, management activity, or supervisory activities perceived as costly. On the other hand, a positively-signed coefficient would suggest that legislators acted in the interest of the public by setting up supervisory institutions to promote product and price competition and to enforce legal restrictions on bank activity.

We include two additional independent variables that follow theories suggesting that regulation is done in the public interest. The first public interest measure is the rate of state bank closures (defined here as either voluntary liquidations or failures) that occurred during the previous decade. ${ }^{31}$ Banks may take on more risk than what is optimal from a depositors' perspective (i.e., moral hazard) as they may not be able to perfectly observe the quality and distribution of loan portfolios. Unable to discern if bank managers were taking on too much risk or committing fraud and worried that they might only receive a fraction of their funds if a bank failed, depositors would be reluctant to put money in the bank, thus making banking institutions less viable. In aggregate, this inefficiency could result in lower investment and output. Hence, asymmetric information could be lessened through supervision by providing independent assessment of accounting information and by checking for management fraud.

The second public interest measure is the logarithm of the ratio total deposits to total circulation for both national and state banks in each state. ${ }^{32}$ In the context of the U.S. banking, the issue of depositor welfare became more pronounced in the latter half of the nineteenth century - when state banks changed their liability structure. Due to the taxation of state bank notes by the federal government, state-chartered commercial banks shifted away from note issuance and toward deposit taking. Depositors typically held funds in just a few banks at most,

\footnotetext{
${ }^{30}$ In the historical context of the United States, Davis (1965), Sylla (1969), James (1976), and Sullivan (2009) argue that the high capital requirements of national banks and taxes on state bank notes after 1865 enabled geographicallysegmented unit banks to obtain considerable monopoly power.

${ }^{31}$ In this case, we normalize bank closures using the sum of the beginning number of banks and the number of bank entries during the period. This approach avoids overstating the rate of closure due to banks that entered and quickly closed.

${ }^{32}$ We use both national and state bank data in order to best capture the overall shift to deposits in state. The approach also avoids the issue of state circulation declining to zero in the decades after the taxation of state bank notes. We add one to the ratio before taking the logarithm to avoid undetermined values.
} 
whereas noteholders often held a variety of notes from banks across the nation. A positive coefficient on the deposit-circulation ratio would indicate that state legislatures responded to the growth in fractional-reserve, deposit banking and the risk of runs on individual banks by creating formal supervisory institutions.

The description of the evolution of banking in the nineteenth and early-twentieth centuries in Section II provides additional factors that may have influenced the decision to adopt formal bank supervisory institutions. We assess whether there were any positive or negative externalities associated with the introduction of national banks in the 1860 s by including the rate of national bank entry and closure. On the one hand, even though the OCC had no regulatory or supervisory authority over state banks, the mere presence of national banks could have created a positive demonstration effect. The Comptroller's Office developed a set of best practices with respect to bank examination, including understanding how accounting procedures and asset portfolios affected risk and failure likelihood. National banking may also have influenced state banking through a legislative requirement passed in 1873, which mandated that the OCC file an annual report describing the banking condition of the entire country. To fulfill this duty, the OCC had to gather information on state banks even though they were outside its formal jurisdiction and implored some states to change their practices. ${ }^{33}$ On the other hand, the presence of national banks could have delayed the establishment of state banking departments, either by creating an incentive to free ride on the OCC or by introducing competition in laxity, i.e., an incentive not to impose costs on state-chartered banks that national banks faced.

State legislatures may have delayed the creation of formal supervisory institutions since they had lower cost substitutes such as double liability laws. Alternatively, the passage of free banking laws, which accelerated the growth in state-chartered banks, could have increased the public demand for supervision. We therefore include dummy variables indicating whether a state had passed a double liability law or had passed and used a free banking law. ${ }^{34}$ While it is possible that the adoption of double liability was endogenous to supervision, very few states

\footnotetext{
${ }^{33}$ It sent regular notices to all state banking departments, requesting information on the state of banking. The OCC even provided copies of bank supervision guidelines for states to use.

${ }^{34}$ There were many states that installed free banking laws but never used them. We therefore only include states that created more than 2 free banks as free banking states. A regression with double liability as the outcome variable and supervision as an explanatory variable shows no statistical relationship between the two.
} 
installed it after supervision. In this way, double liability seems to have been an early attempt to prevent bank risk taking without devoting any resources to do so.

We do not, however, include dummy variables for reserve requirements or deposit insurance systems because, as discussed above, they were largely installed after formal supervisory institutions. ${ }^{35}$ Although some states appear to have considered state banking departments a necessary condition for enacting regulation, the timing of the adoption of state deposit insurance systems does not work in favor of a hypothesis that these somehow served as an impetus for the creation of independent bank supervisory departments.

In lieu of regulation in the public interest, it is possible that banks could act jointly and come up with collective mechanisms that would prevent spillovers to each other or to the economy. ${ }^{36}$ The establishment of clearinghouses could have been one such private-sector response. Clearinghouses were established to facilitate the clearing of checks and notes, but they also collected financial statements and had the power to examine member banks. We therefore include a dummy variable denoting whether a clearinghouse was operating in the state at the end of the decade. To the extent that a clearinghouse mediated the need for the adoption of government solutions, the predicted sign of clearinghouses on the creation of state banking departments would be negative. We can only include clearinghouses when looking across the entire period because (1) only Maryland installed a clearinghouse before supervision in the antebellum and (2) the clearinghouse dummy becomes nearly collinear with the region dummies once banks that installed supervision are dropped out of the postbellum sample.

We include a variety of controls to capture other state and region specific factors that may have also influenced the decision to create state banking departments. We examine the extent to which a state's level of development might have influenced the establishment of permanent supervisory institutions by including the number of state banks per capita at the end of a decade (as well as its square), the log of a state's population, the urbanization rate (defined as those places with more than 2,500 people), and the percent of the population that is non-

\footnotetext{
${ }^{35}$ When these additional variables are included in the estimation, the results are quite similar to those shown in Table 1.

${ }^{36}$ In practice such practices have been few and far between as a result of coordination problems. Calomiris and Schweikart (1991) note that several states responded to the Panic of 1857 by developing coordination technologies.
} 
white. ${ }^{37}$ Since the timing of adoption may have been influenced by geographical differences such as banking market structure, regional indicator variables are also included as controls. ${ }^{38}$ For example, the general lack of state supervision in the South prior to the Civil War was likely a result of the use of state-sponsored banks in that region. These banks served the state, holding their deposits, were permitted to branch throughout a state, and were protected by large capital stocks. The resulting small number of other commercial banks may thus have limited the incentives for legislatures to develop costly supervision. ${ }^{39}$

\section{Explaining the Adoption of State Bank Supervision}

Estimating a hazard model over the entire sample period of 1820-1910 has the virtue of statistical power; however, it is less useful for taking into account evolving legislative priorities given structural changes in the American banking system. For example, in the antebellum period, state legislatures liberalized entry requirements with free banking laws. Because deposit accounts were fairly limited and note issuance was fully collateralized, banking largely grew unabated and there were few advances in supervision. However, by the postbellum period, the National Banking Acts gave rise to competition between state banks and national banks and to the rapid growth of banks funding their investments via deposits rather than notes. Because legislative priorities may have shifted in response to these structural changes, the estimation and interpretation of some of our coefficients using the entire sample period is sometimes problematic. For example, before 1870, the hazard model will assign values of zero to national bank entries and closures instead of a null value even though no national banks existed. We therefore also present estimates for the sub-sample periods of 1820-1860 and 1870-1910. We discuss the sub-sample estimates when we want to highlight how the perceptions of state legislatures may have been altered by structural breaks in American banking.

\footnotetext{
${ }^{37}$ To provide coefficients of reasonable size, per capita is defined per 100,000 people. We cannot include measure of economic activity such as manufacturing and agricultural output because these types of measure were only widely collected after 1840 .

${ }^{38}$ Dummies for the South, Midwest, and West are included, with the Northeast being the omitted category.

${ }^{39}$ Louisiana stands out as the clear exception. It established a board of commissioners in 1842, and improved the quality of supervision with its free banking law in 1853 by requiring weekly statements of condition, uniform quarterly reporting (including details on loans by maturity), and annual bank examinations. In this way, the state was on par with New York and Massachusetts and surpassed the level of supervision in most other states.
} 
Table 1 shows that periods of state banking distress help to predict when formal supervision were put in place. The rate of state bank closures accelerated the establishment of formal supervision across both the antebellum and the postbellum periods. Based on the underlying hazard ratios, a 10 percent higher closure rate in state banks would nearly double the probability of installing formal supervision. On the other hand, national bank closure rates are not significantly correlated with the adoption of state banking departments in the postbellum period.

Consistent with public interest theory, state policymakers thus may have been more compelled to change supervisory practices in response to distress for banks they had chartered (i.e., state banks) in comparison to those that may have created negative spillovers but for which they had no chartering authority (i.e., national banks). As with other bureaucracies, state-banking departments persisted once they were established. Therefore, a state had to be willing to commit to operational costs indefinitely. In normal periods, when losses were relatively low, states might not have seen the benefit in obligating themselves to future taxpayer liabilities. It appears that it was not until financial panics and widespread state bank depositor losses united constituencies that politicians were forced to act in the public interest. For instance, in its first report in 1893, Pennsylvania's superintendent of banking states that before the creation of the department:

It does not appear that any one of our Auditors General has ever been afforded proper assistance for the discharge of his duties relating to banks and saving funds. In fact, beyond receiving and publishing the quarterly reports of those institutions which were made to the Auditor General, and occasional appointments of special examiners, further supervision does not seem to have been expected of them ... Time and again [State Auditors] have called particular attention to the necessity of a closer state supervision of banks. Had some of their recommendations been adopted ... the unfortunate and disreputable failures that have recently occurred, would have been halted at a time to prevent so serious a damage as has happened, and so disgraceful a stain placed upon our banking- annals both state and national (Krumbhaar 1893, 1-2).

State legislatures also might have responded to the high bank resolution costs that emerged from banking panics. Kentucky's banking commissioner's first report confirms that this as an additional reason for installing formal institutions: 
Prior to 1912, there were few safeguards thrown around banking institutions in this State. The frequency with which bank failures occurred led the Legislature, in 1912, to pass a comprehensive act looking toward the regulation, examination and proper conduct of all State banks, and providing for the closing and winding up of the affairs of all such as were found to be in an insolvent condition. This legislation has, as its ultimate aim the protection of the depositing public (Smith 1913, VI).

Without a staff of examiners, court officials of the state would have been saddled with the time consuming process of obtaining records of bank assets, negotiating with loan customers, and tracking down stockholders; court-ordered liquidations can be slow, and can delay the redeployment of productive assets back into the economy (Anari, Kolari, and Mason 2000). ${ }^{40}$ Hence, in the wake of failures and economic disruptions associated with them, legislatures may have been compelled to set up permanent supervisory institutions to reduce resolution costs and time.

Table 1 also indicates that faster bank growth rates accelerated the creation of formal supervision across the whole period. For state bank entry, the effect is relatively small. A 10percentage-point increase in the rate of entry of state banks raised the probability of installing formal state bank supervision by about 0.2 percent per year over the period 1820-1920. The positive sign indicates that policymakers were not delaying supervision to protect local monopolies. Policymakers, however, appear more concerned about the growth of national banking systems. A 10-percentage-point increase in the rate of national bank entry raised the probability by 1.7 percent per year over the whole sample period. ${ }^{41}$ The positive coefficient is consistent with regulation in the public interest since legislatures wanted their state banking systems to flourish in the face of competition from national banks. White $(1983,2010)$ has shown that this competition often resulted in lower capital and reserve requirements, but states may have also attempted to draw banks away from the federal system by offering an alternative to the OCC. Our result suggests a potential positive spillover from the competition between state and national banks.

\footnotetext{
${ }^{40}$ For example, OCC examiners checked to make sure all stockholder information for national banks was up to date and a few states even published detailed information on stockholders in their annual reports.

${ }^{41}$ It is also possible that state legislatures installed formal supervision after observing the stability of national banks or in order to avoid spillover effects.
} 
Consistent with regulation in the public interest, the switch from circulation to deposits also raised the likelihood of state legislatures establishing state banking departments. As expected, the coefficient is statistically insignificant in the antebellum period when deposits were consistently low and held mostly by firms. However, it is statistically significant and positively signed in the postbellum period. A state that had double the number of deposits relative to circulation was about eleven times more likely to install supervision during the postbellum than a state that had a ratio of one. Since depositors were generally more susceptible than noteholders to losses associated with idiosyncratic bank risk, we interpret this as an indication that elected legislators (who were accountable to depositors) began to pay more attention to the operations of individual banks. Because the rise of deposits pushed banks to expand their loan portfolios relative to bond purchases, the shift would have more closely connected to economic and financial health as well (Calomiris and Mason 2008). Therefore, as deposits became more widely held, policymakers sunk the cost of creating state banking departments in the public interest.

Double liability also sped up the introduction of bank supervision. Over the period 18201910, a state with a double liability law in place was sixteen times more likely to install a separate banking department than a state without a law. Two-thirds of states passed double liability laws prior to establishing formal bank supervision, and most installed it a couple decades prior (Figure 4). Therefore, double liability was the first widely pursued bank regulation at the state level, and states only appear to have established costly supervision after double liability had been found lacking. As states experienced significant numbers of bank failures, legislators and depositors likely learned, through first-hand experience, how hard it was to track down and obtain payments from stockholders without the help of formal institutions charged with this responsibility. In the wake of banking distress, state banking departments and improved supervision thus may have evolved to improve the effectiveness of double liability laws (Carlson 2014).

Free banking laws were installed during the antebellum period, but they did not have a statistically significant effect during that period. Instead, they slowed down the adoption of supervision across the entire period. A state that passed a free banking law was about half as likely to install a separate bank authority as other states. 
While a few states installed independent supervisory departments during the antebellum period, their adoption was slow and primarily driven by financial panics. The latter half of the nineteenth century marks an important shift toward a system of state bank supervision that began to deal with the negative externalities associated with fractional reserve banking and deposittaking financial institutions. However, states initially pursued cheaper options for reigning in bank behavior, such as double liability for bank stockholders, and again, only devoted significant resources to formal supervision after periods of banking distress. The competition between state and national banks also played a role in speeding up the adoption of formal supervision.

\section{Quality of State Bank Supervision}

As shown in Figures 3 and 4, adoption of formal supervision by states was nearly completed by the first decades of the twentieth century. That said, the quality of state banking departments varied considerably across states. The size of examination staffs, expenditure to support examination activities, and the quality of data collected by examiners differed considerably. To learn more about the determinants of differences in the quality of supervision, we first examine when states began to publish separate banking reports using the same hazard model framework as in the previous section. We then analyze how reported measures of expenditures and staffing of examination departments differed in 1911 - after most states had created formal bank supervisory institutions.

Some state banking departments began to publish detailed and standardized bank balance sheet data beginning in the antebellum era, but most states failed to collect detailed balance sheet information even on an annual basis. As this type of information was important for the public to reliably monitor banks, it is a key measure of the quality of bank supervision. As shown in Panel B of Figure 3, the practice of collecting standardized information on banks began in the Northeast and slowly diffused westward. Many states in the Northeast published banking reports prior to the 1870s, with other regions lagging. The Great Plains began in the 1890s, the Pacific Northwest in the 1900s, and the Southwest in the 1910s. 
Table 2 estimates a hazard model predicting when states began publishing regular and periodic balance sheets over the period $1820-1910 .^{42}$ As might be expected, states that created permanent bank supervisory institutions were significantly more likely to publish annual reports on the balance sheets of banks in the postbellum era. A state that established a separate bank authority was about 10 times more likely to publish a detailed bank report than a state without one. We also find that the rates of national bank entry and closure encouraged the publication of separate bank reports. The former finding is likely driven by the state's concern over spillovers, whereas the latter finding likely driven by the mandate of the OCC to collect state bank data. ${ }^{43}$ Consistent with our earlier discussion, the move to deposit-taking banks as well as laws mandating the payment of double the owner's equity in the event of a bank's failure encouraged publication of annual balance sheets.

In 1911, the Comptroller of Currency published results from a survey that provided information for each state's expenditure on bank supervision, the number of examiners on staff, and the number of examinations conducted during the previous year. ${ }^{44}$ Figure 5 shows state-level differences in expenditures by banking departments and the number of examiners hired. Because the Comptroller only surveyed state banking departments for a single year, we explore the crossstate differences in supervisory quality using an OLS model and a rich set of predictive variables.

As might be expected, having a state banking department is associated with increased expenditure on bank supervision and more bank examinations in Table 3. States with bank supervisory departments spent nearly five times more in total and 1.7 times more per state bank in comparison to the nine states that had not created them by 1911. States that had created their supervisory departments earlier also spent more on supervision and examined banks more frequently than other states, perhaps indicating that these states used the additional funds to increase the quality of their supervision. The presence of double liability laws increased the number of examinations in a year, whereas free banking appears to have had no residual impact

\footnotetext{
${ }^{42}$ We cannot estimate the model using only antebellum data because few states published a report before 1870 .

${ }^{43}$ The general lack of state reporting and national banking before 1870 upwardly biases the coefficient on national bank closures in column two of table 2; hence we view the postbellum result shown in column 1 as the more reliable estimate.

${ }^{44}$ Because the Comptroller did not receive information on Alabama, Illinois, or Louisiana, they are dropped from the sample.
} 
on the quality of bank supervision (at least after controlling for the number of banks in a state). Based on the regressions, a state that installed double liability made about 126 percent more examinations in total and about 25 percent more examinations per bank than states that had maintained single liability.

The number of national banks is associated with increased spending on supervision as well as the number of bank examiners, perhaps an unintended benefit of competition between federal and state regulators. Based on the model, a one-standard-deviation increase in the number

of national banks per capita (i.e., 5.3 banks) increased the total amount spent on supervision by at least 130 percent and the number of examiners 3.0. Consistent with the fact that some states published data on national banks, the regressions indicate that states devoted resources to watch over national banks. Alternatively, the number of state banks is only statistically significant in Column 3. The relative insignificance of state banks is likely due to the fact that banking departments would have to spend more as the number of banks increased, but would be able to spend less per bank.

\section{Conclusion}

From the outset, government officials in the U.S. were skeptical of giving banks too much power and autonomy. The first attempts at state bank supervision focused on assessing whether banks had sufficient paid-in capital to open for business and whether they had sufficient assets to back up the notes they issued. Policymakers in the early nineteenth century appear to have paid little attention to systemic risk. A century later, state bank supervision, though far from perfect, had made considerable strides toward modern standards and objectives. The vast majority of U.S. states had established separate state banking departments by the time the Federal Reserve System was founded.

Using a new data set on the establishment of formal supervision, we show that state banking departments, which employed dedicated, supervisory staff to conduct regular and periodic examinations, were slow to emerge. The large initial fixed costs of establishing such institutions appear to have been one factor that influenced state legislatures' choice to use far 
cheaper regulatory systems based around double liability requirements for stockholders. Repeated and costly banking crises, however, moved states to look beyond the cheaper options, and forge permanent agencies devoted to bank examination. Twenty-seven states installed supervision immediately after one of the period's three major panic periods: 1837/1839, 1890/1893, and 1907.

As we show, there are several reasons why states likely chose to install supervision after panics. First, public outcry after large or widespread banking failures increased the demand for financial stability. As banks changed from issuing collateralized notes to uncollateralized deposits, more and more individuals became exposed to the negative effects of fraudulent behavior and financial crises. Elected officials in the postbellum were increasingly accountable to taxpayers holding bank deposits and supervising in the public interest. Second, state officials likely learned that banking distress could involve sizable resolution costs. Liquidating banks meant taking accurate account of all failed banks' assets, wrapping up loans, and tracking down any stockholders who were liable for losses. Politicians might have been able to more easily justify the expenses associated with permanent state banking departments if they could reduce resolution costs by using qualified supervisory staff to liquidate banks. Finally, if legislators could make the claim that state-banking departments prevented future failures, then supervision in the public interest may have become more palatable to taxpayers. Ex post, there appears to be some evidence to support this conjecture. During the next severe banking crisis to hit the U.S. economy, states with higher quality bank supervisory departments experienced fewer failures during the Great Depression (Mitchener 2005, 2007).

Our findings from an analysis of the timing of the publication of state banking reports and the 1911 Comptroller's survey of state banking departments speak somewhat further to this point, suggesting that institutional learning may help account for differences in supervisory quality that were apparent in the 1930s. Looking at when states began publishing regular and periodic reports, we find that very few states published detailed data before an independent authority had been established. The states that created permanent state banking departments the earliest also tended to have the most detailed summary of bank portfolios. Looking at the 1911 Comptroller's survey of state banking departments, those states that established independent 
supervisory agencies earlier had banking departments that, on average, spent more on supervision and carried out more examinations. To the extent that better information and more examinations improve systemic stability, the timing of supervision installation is important.

Finally, while previous research has drawn attention to how the dual banking system may have promoted laxity in regulation, our analysis suggests somewhat different results for supervision. $^{45}$ For example, we find that states accelerated the adoption of permanent bank supervisory institutions in the face of greater competition from national banks. Of course, this may have been an unintended consequence of a chartering race whereby states offered an alternative regulatory and supervisory environment to draw banks away from the national banking system. That said, the national banking system also appears to have enhanced the quality of state supervisory institutions. During the 1870 s, the Comptroller of the Currency pushed states to collect and release bank data with regular frequency. We also find that national bank activity is positively associated with state banking systems carrying out more examinations and having more examiners to do so.

\footnotetext{
${ }^{45}$ See for instance White $(1983,2011)$ and Agarwal, et al. (2011).
} 


\section{References}

Agarwal, Sumit, David Lucca, Amit Seru, and Francesco Trebbi. (2011). "Inconsistent Regulators: Evidence from Banking." NBER Working Paper 17736.

Anari, Ali, Joseph Mason, and James Kolari. (2000). "The Speed of Bank Liquidation and the Propagation of the U.S. Great Depression." In Bank Structure and Competition Conference Proceedings. Chicago: Federal Reserve Bank of Chicago.

Barnett, George. (1911). State Banks and Trust Companies since the Passage of the NationalBank Act. $61^{\text {st }}$ Congress, $3^{\text {rd }}$ Session, Senate Document 659. National Monetary Commission. Washington: Government Printing Office.

Bodenhorn, Howard. (2003). State Banking in Early America: A New Economic History. New York: Oxford University Press.

Bodenhorn, Howard and David Cuberes. (2010). "Financial Development and City Growth: Evidence From Northeastern American Cities, 1790-1870.” NBER Working Paper 15997.

Bernanke, Ben. (1983). "Non-Monetary Effects of the Financial Crisis in the Propagation of the Great Depression." American Economic Review 73: 257-276.

Bolles, Albert. (1888). The National Bank Act and Its Judicial Meaning. New York: Homans Publishing Company.

Calomiris, Charles W. and Charles Kahn. (1991). "The Role of Demandable Debt in Structuring Optimal Banking Arrangements." American Economic Review 81: 497-513

Calomiris Charles W. and Larry Schweikart. (1991). "The Panic of 1857: Origins, Transmission, and Containment." Journal of Economic History 51(4): 807-34.

Calomiris, Charles W. and Mason, Joseph R. (2008). "Resolving the puzzle of the underissuance of national bank notes," Explorations in Economic History 45: 327-355.

Carlson, Mark. (2014). "Lessons from the Historical Use of Reserve Requirements in the United States to Promote Bank Liquidity". Unpublished Working Paper.

Catterall, Ralph. (1903). The Second Bank of the United States. Chicago: University of Chicago Press.

Chen, Nan-Kuang. (2001)."Bank net worth, asset prices and economic activity." Journal of Monetary Economics 48: 415 - 436.

Comptroller of the Currency. Various Years. Report. Washington: Government Printing Office.

Davis, Andrew. (1910). The Origin of the National Banking System. Washington: US Government Printing Office.

Davis, Lance. (1965). “The Investment Market, 1870-1914: The Evolution of a National Market." Journal of Economic History 25: 355-399.

Dehejia, and Adriana Lleras-Muney. (2007). "Financial Development and Pathways of Growth: State Branching and Deposit Insurance Laws in the United States, 1900-1940." Journal of Law and Economics 50: 239-272.

Dewatripont, Mathias and Jean Tirole. (1993). "Efficient Governance Structure: Implications for Banking Regulation." In Capital Markets and Financial Intermediation, pp. 12-35. Edited by Colin Maye and Xavier Vives. Cambridge: Cambridge University Press. 
Diamond, Douglas and Philip Dybvig. (1983). "Bank Runs, Deposit Insurance, and Liquidity." Review of Economic Studies 51: 392-414

Esarey, Logan. (1912). "State Banking in Indiana, 1814-1873." Indiana University Studies 15.

Friedman, Milton and Anna Jacobson Schwartz. (1963). A Monetary History of the United States 1867-1960. Princeton: Princeton University Press.

Gorton, Gary. (1996). "Reputation Formation in Early Bank Note Markets.” Journal of Political Economy 104: 346-97.

Grossman, Richard. (2001). "Double Liability and Risk-Taking." Journal of Money, Credit, and Banking 33: 143-159.

Grossman, Richard. (2007). " Fear and greed: The evolution of double liability in American banking, 1865-1930". Explorations in Economic History 44: 59-80.

Grossman, Richard. (2010). Unsettled Account: The Evolution of Banking in the Industrialized World Since 1800. Princeton: Princeton University Press.

Gruchy, Allan Garfield. (1937). Supervision and Control of Virginia State Banks. D. AppletonCentury Co., New York.

Haines, Michael R. (2004). Historical, Demographic, Economic, and Social Data: The United States, 1790-2000. ICPSR Study 2896. Ann Arbor, MI: Inter-university Consortium for Political and Social Research.

Hammond, Bray. (1957). Banks and Politics in American from the Revolution to the Civil War. Princeton, NJ: Princeton University Press.

Holdsworth, John T. and Davis R. Dewey. (1910). The First and Second Banks of the United States. Washington: Government Printing Office.

James, John. (1976). "The Development of the National Money Market: 1893-1911". The Journal of Economic History 36: 878-897.

Jaremski, Matthew. (2010). "Free Bank Failures: Risky Bonds vs. Undiversified Portfolios." Journal of Money, Credit, and Banking 42: 1565-1587.

Jaremski, Matthew (2014). “Clearinghouses as Credit Regulators Before the Fed?" Forthcoming Journal of Financial Stability.

King, Robert. (1983). "On the Economics of Private Money." Journal of Monetary Economics 12: $127-158$.

Krumbhaar, C.H. (1893). Reports of the Several Banks, Savings Institutions, and Trust Companies of Pennsylvania. Harrisburg: Edwin K Meyers, State Printer.

Lamoreaux, Naomi R. (1986). "Banks, Kinship, and Economic Development: The New England Case." Journal of Economic History 46: 647-667.

Lamoreaux, Naomi R. (1994). Insider Lending: Banks, Personal Connections, and Economic Development in Industrial New England. Cambridge: Cambridge University Press.

Lebergott, S. (1970). "Migration within the U.S., 1800-1960: Some New Estimates". Journal of Economic History 30: 839-847.

Marquis, Ralph W., and Frank P. Smith. (1937). "Double Liability for Bank Stock”. American Economic Review 27: 490-502.

Meh, Cesaire A. and Kevin Moran. (2010). "The Role of Bank Capital in the Propagation of Shocks." Journal of Economic Dynamics and Control 34: 555-576.

Mihm, Stephen. (2007). A Nation of Counterfeiters: Capitalists, Con Men and the Making of The United States. Cambridge: Harvard University Press. 
Mishkin, Frederic S. (2001). "Prudential Supervision: Why Is It Important and What Are the Issues?" In Prudential Supervision: What Works and What Doesn't Frederic S. Mishkin (ed.) Unversity of Chicago Press: 1-30.

Mitchener, Kris James. (2005). "Bank Supervision, Regulation, and Financial Instability during the Great Depression." Journal of Economic History 65: 152-85

Mitchener, Kris James. (2007). "Are Supervision and Regulation Pillars of Financial Stability? Evidence from the Great Depression." Journal of Law and Economics 50: 273-302.

Mitchener, Kris James and Gary Richardson. (2013). "Skin in the Game? Risk, Leverage, and the Consequences of New Deal Financial Legislation." Explorations in Economic History 50: 508-25.

Peltzman, Sam. (1976). "Toward a More General Theory of Regulation." Journal of Law and Economics 27: 211-240.

Peltzman, Sam. (1984). "Constituent Interest and Congressional Voting." Journal of Law and Economics 84: 181-210.

Posner, Richard A. (1971). "Taxation by Regulation." Bell Journal of Economics and Management Science 2: 22-50.

Posner, Richard A. (1974). "Theories of Economic Regulation," Bell Journal of Economics and Management Science 5: 335-88.

Robertson, Ross. (1968). The Comptroller and bank supervision: a historical appraisal. Washington D.C.: Office of the Comptroller of the Currency.

Rajan, Raghuram. (2009). "The Credit Crisis and Cycle-Proof Regulation." Federal Reserve Bank of St. Louis Review 91: 397-402.

Rockoff, Hugh. (1974). "The Free Banking Era: A Reexamination.” Journal of Money, Credit, and Banking 6: 141-167.

Rodkey, R. G. (1934). "Legal Reserves in American Banking". Michigan Business Studies VI.

Rolnick, Arthur J. and Warren E. Weber. (1983). "New Evidence on the Free Banking Era." American Economic Review 73: 1080-1091.

Smith, Thomas. (1913). First Annual Report of the Bank Commissioner of the Commonwealth of Kentucky. Frankfort, KY: The State Journal Company.

Sprague, Oliver. (1910). History of Crises Under the National Banking System. Washington D.C.: National Monetary Commission.

Stigler, George J. (1971). "The Theory of Economic Regulation." Bell Journal of Economics and Management Science 2: 3-21.

Sullivan, Richard J. (2009). "Regulatory Changes and the Development of the US Banking Market, 1870-1914: A Study of the Profit Rates and Risk in National Banks." In The Origins and Development of Financial Markets and Institutions. Cambridge: Cambridge University Press.

Sylla, Richard. (1969). "Federal Policy, Banking Market Structure, and Capital Mobilization in the United States, 1863-1913." Journal of Economic History 29: 657-686.

Temin, Peter. (1969). The Jacksonian Economy. New York: W.W. Norton \& Company.

Townswend, Robert M. (1979). "Optimal Contracts and Competitive Markets with Costly State Verification." Journal of Economic Theory 21: 265-93.

Trescott, Paul B. (1963). Financing American enterprise. New York: Harper and Row. 
Weldon, Samuel. (1910). Digest of State Banking Statutes. U.S. National Monetary Commission. Washington: GPO. 61st Congress, 2nd session, Senate, Document no.353.

Weber, Warren. (2005). "Listing of all State Banks with Beginning and Ending Dates." Research Department, Federal Reserve Bank of Minneapolis. http://research.mpls.frb.fed.us/research/economists/wewproj.html.

Weber, Warren. (2008). "Balance sheets for U.S. Antebellum State Banks." Research Department, Federal Reserve Bank of Minneapolis http://research.mpls.frb.fed.us/research/economists/wewproj.html

Weber, Warren. (2011). "Bank Liability Insurance Schemes Before 1865." Research Department, Federal Reserve Bank of Minneapolis Working Paper 679.

White, Eugene. (1983). The Regulation and Reform of the American Banking System, 19001929. Princeton: Princeton University Press.

White, Eugene. (2009). "Lessons from the History of Bank Examination and Supervision in the Unites States, 1863-2008," In Financial Market Regulation in the Wake of Financial Crises: The Historical Experience. Banca d'Italia Eurosistema, Rome, pp. 15-44.

White, Eugene. (2011). "To Establish a More Effective Supervision of Banking": How the Birth of the Fed Altered Bank Supervision.” NBER Working Paper 16825. 


\section{Data Appendix}

\section{$\underline{\text { Banking Data }}$}

We obtain the number of banks, bank entry, and bank closure data from two types of sources. We start with Weber's antebellum bank census (2005), which contains the location and dates of operation for every bank before 1861. We then extend his banking census through 1910 using the Merchants and Bankers' Directory (1860-1889), Rand McNally Bankers' Directory (1890-1900), and Polk's Bankers Encyclopedia (1901-1910). These bank directories are reported to provide, "a complete list of banks, bankers, savings banks, and principle trust companies." The directories include the name, location, and capital of each bank, as well as whether they were chartered by a state legislature or the Comptroller of the Currency. Therefore, by comparing the directories in successive years, we can determine when a bank was chartered and when it exited. A drawback of using these directories is that they do not permit us to determine if banks exited due to merger, voluntary liquidation, or failure (involuntary liquidation). Even so, the data provide the most comprehensive census of banking activity for the nineteenth century. As a check on the completeness of the directory data, we confirmed that the totals matched those reported in published state banking reports (when the latter became available).

The circulation and deposit data come from Weber (2005) for the antebellum era, and the various issues of the Annual Report of the Comptroller of the Currency for the postbellum era.

\section{Date of Establishment of Independent Bank Authority}

We define this as the year when a state installed its first independent banking state banking authority. These agencies went by various names, the most common of which were the Office of the Bank Examiner, Bank Commissioner, or State Banking Department. While individual states' departments differed, they all shared the common feature of focusing on banking, rather than insurance businesses or general business incorporation. In our analysis, we make no distinction between states that referred to the head of the agency as a bank commissioner, a bank comptroller, or a banking superintendent. We obtained dates using a

\footnotetext{
${ }^{46}$ We combine trust companies, savings banks, and savings and loan banks under the "state bank" category as all of them usually reported to the same authority.
} 
variety of sources. Two published sources listed the dates of bank commissioners (Gruchy 1937) and banking departments (Weldon 1910), but these are incomplete and contain some errors based on our other data collection. We therefore conducted two surveys of 48 state banking departments (in 2002-3 and a follow up in 2012), soliciting official documentation on the origin of their departments (denoted "state historical documents" in appendix Table A1). Through these surveys, we obtained histories of state banking departments in the form of printed information or web-based official histories; however, a significant number of states did not respond. Hence, we utilized published state banking department reports from the first years of their existence, which we were able to locate for almost all states in our sample; these contained useful information on the enactment of state banking laws and the founding of the state banking departments. Whenever there were conflicts in the information we obtained, we used those dates from latter two sources rather than from the secondary sources. The sources used to obtain these for each state are provided in Table A1.

\section{Double Liability on Bank Stockholders}

This dummy value takes on positive values once a state passed a law legislating double, triple, or unlimited liability for bank stockholders. Those states that did not have a liability law or had an ambiguous law are not considered to have double liability. We obtained these dates as well as the date of removal from a variety of sources. First, we sorted through the NBER State Constitutions Database (http://www.stateconstitutions.umd.edu/index.aspx $)$ for keywords such as bank, shareholders, stockholders, liable, liability, and double. We augmented these data using Barnett $(1911,76-77)$ and the compiled statutes of each state. Second, we used Marquis and Smith (1937) to obtain the dates of some states that adopted double liability in the antebellum period and Grossman (2001, 2007) and Mitchener and Richardson (2013) for dates of some states in the postbellum. We obtained the remaining dates from the following sources: Paton's Digest of Legal Opinions, Broom's First Hundred Years of North Carolina Banking, The Pacific Reporter, and The Atlantic Reporter. 


\section{$\underline{\text { Reserve Requirements on Deposits }}$}

We obtained these the dates when a state first required all banks to holder reserves on depostis from Rodkey (1934).

\section{Deposit Insurance}

We obtain the dates of deposit insurance for the antebellum period from Weber (2011) and for the postbellum period from Dehejia and Lleras-Muney (2007, Table 1).

\section{$\underline{\text { Publication Date of Separate Banking Reports }}$}

This is defined as the first year that a state published a separate report on banking. The distinction is necessary because some states reported a small amount of banking information in an omnibus report that also contained information on population, education, farming, and

finances, which we do not code as constituting a banking report. We gathered the dates directly from the reports themselves (i.e., dates of first published volumes), denoted in appendix Table A2 as "published first report." Many state reports are digitized and available on the internet; others were tracked down through the Library of Congress and state libraries. For the few states that we were not able to obtain the first report, we obtained the year of the first volume through its library entry or through its numbering scheme (e.g. if the $8^{\text {th }}$ annual report was published in 1908, the first was likely 1900), denoted as "Worldcat" in appendix Table A2. The list of sources are provided in Table A2.

\section{Population Data}

Figures on each state's total population as well as the fractions living in an urban area and that were non-white are from census data assembled by Haines (2004).

\section{$\underline{\text { Clearinghouse Data }}$}

The dates of clearinghouse establishment were obtained from Jaremski (2014). Because they are listed by city, we selected the earliest year that a clearinghouse operated in a particular state to generate the dummy variable used in the paper. 
Figure 1: Number of Banks and Ratio of Deposits to Circulation, 1820-1910

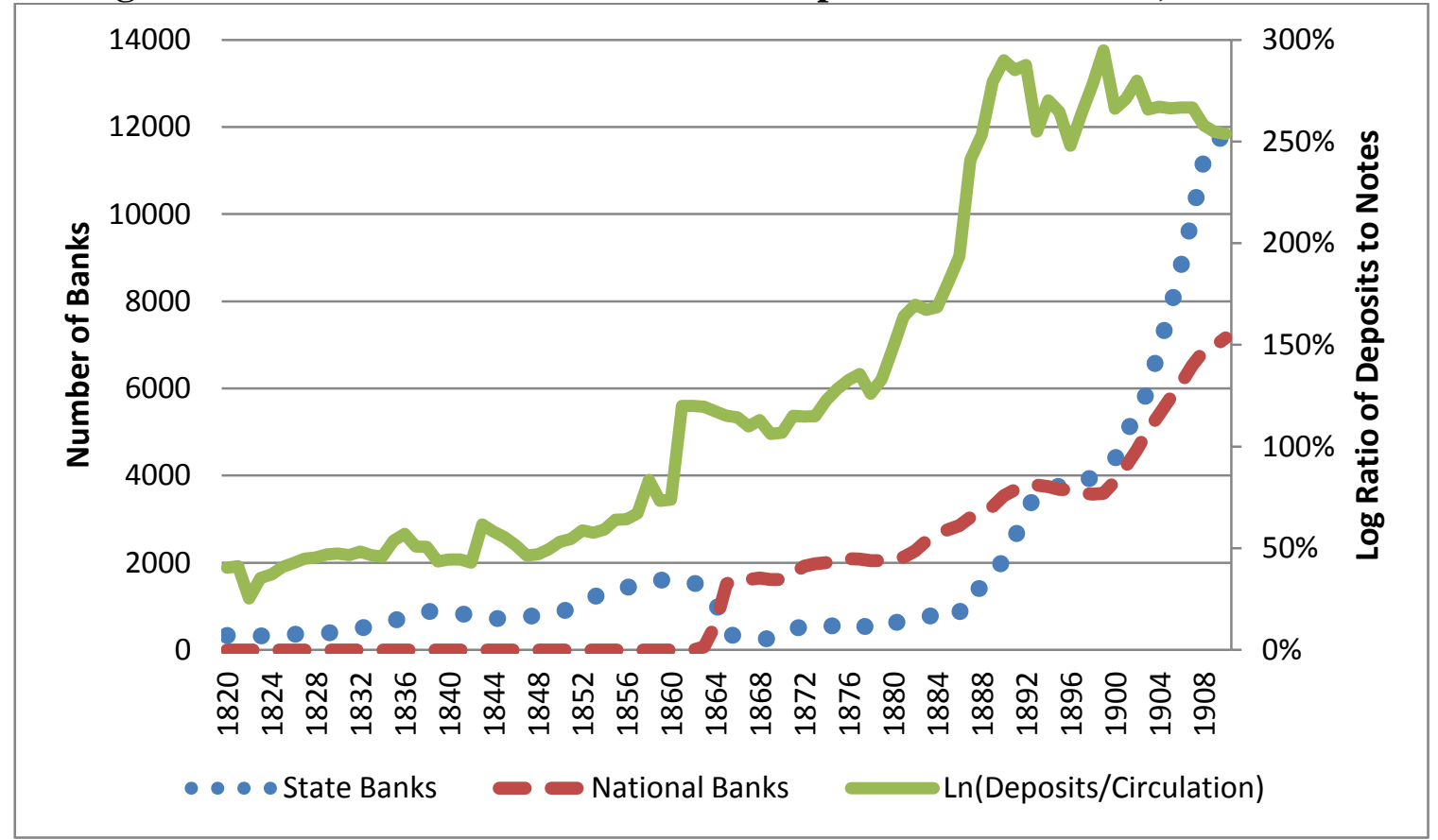

Notes: The number of state banks and the ratio of individual deposits to notes in circulation before 1861 are from Weber $(2005,2008)$. The number of state and national banks and ratio of deposits to notes after 1860 come from the Annual Report of the Comptroller of the Currency. We add one to the deposit to circulation ratio in order to avoid undefined numbers. 
Figure 2: Year When Double Liability First Installed

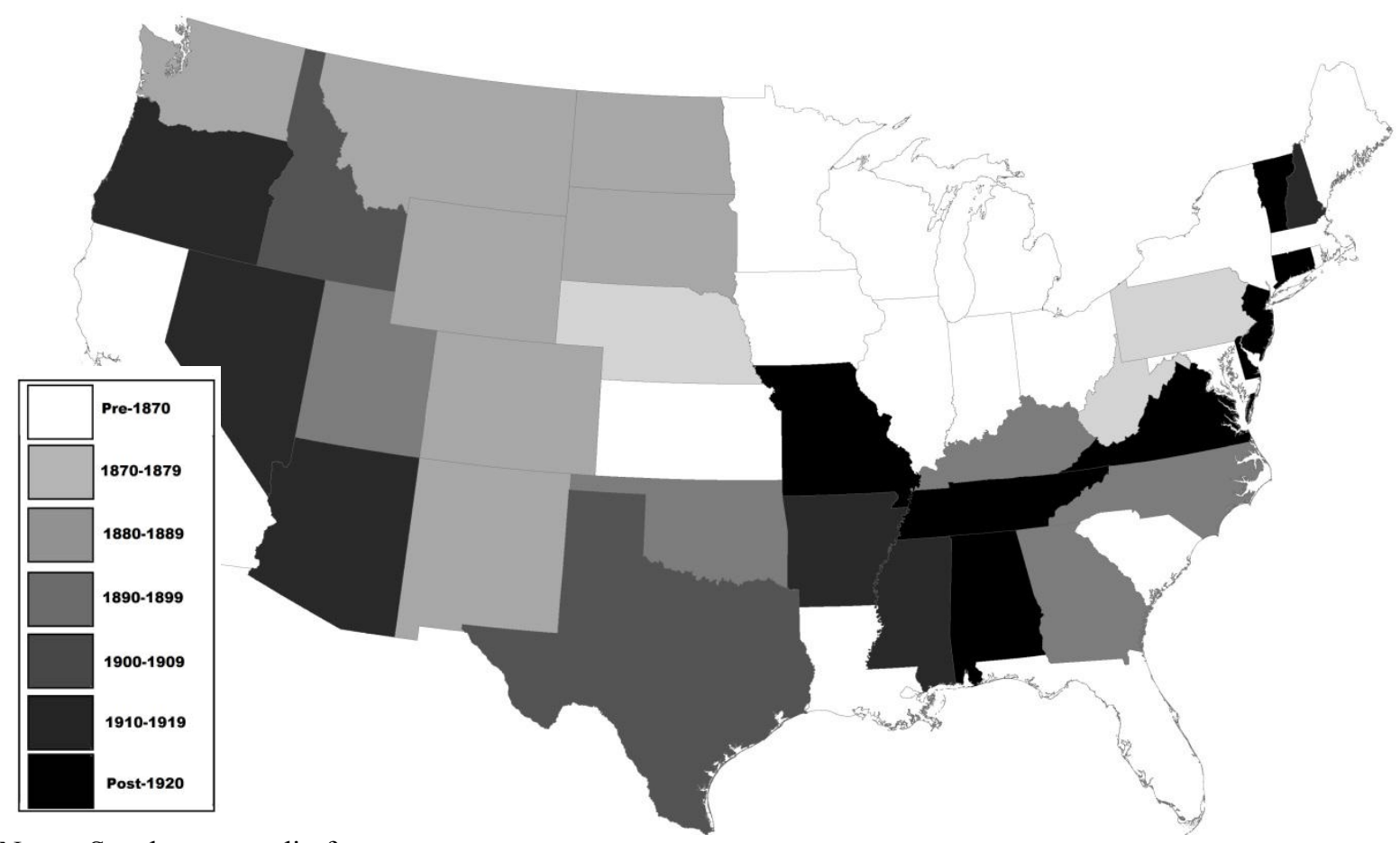

Notes: See data appendix for sources. 
Figure 3: The Evolution of State Bank Supervision Panel A: Year When Separate Banking Authority Authorized

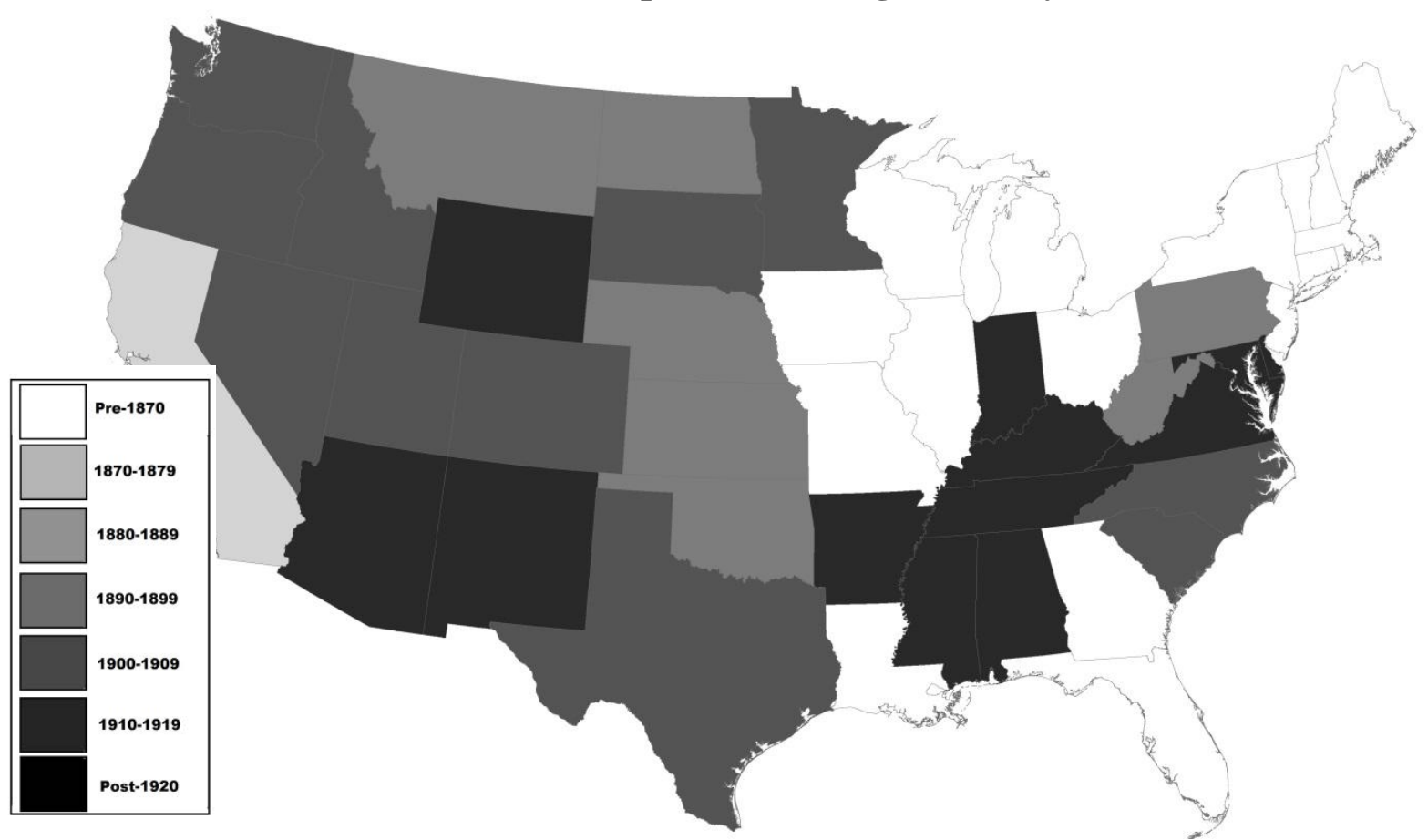

Panel B: Year When State Began Publishing Detailed Report on Banks

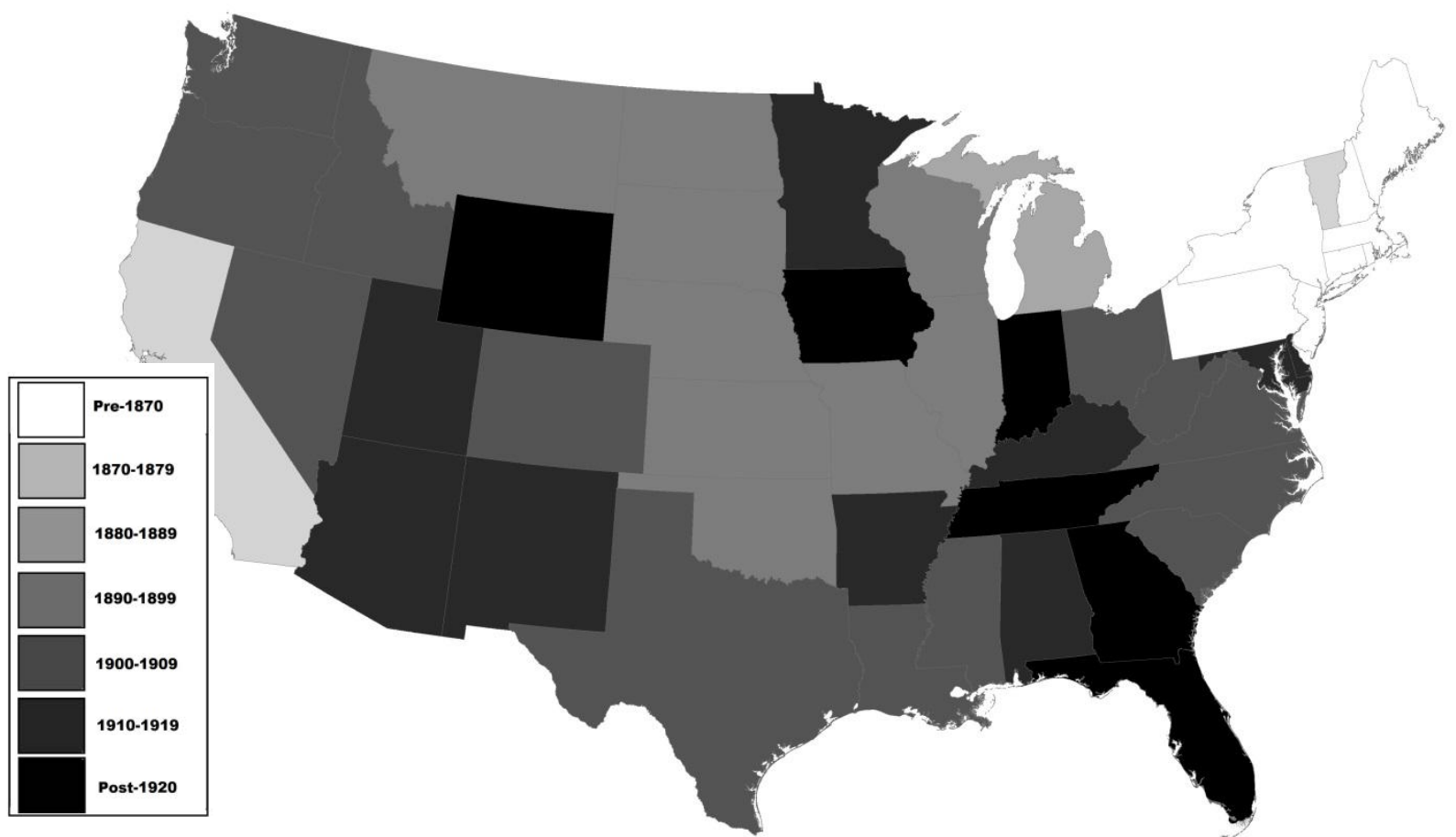

Notes: See data appendix for sources. 
Figure 4: Adoption Rates for State Bank Supervision and Regulation, 1820-1914 (Rate of Existing States)

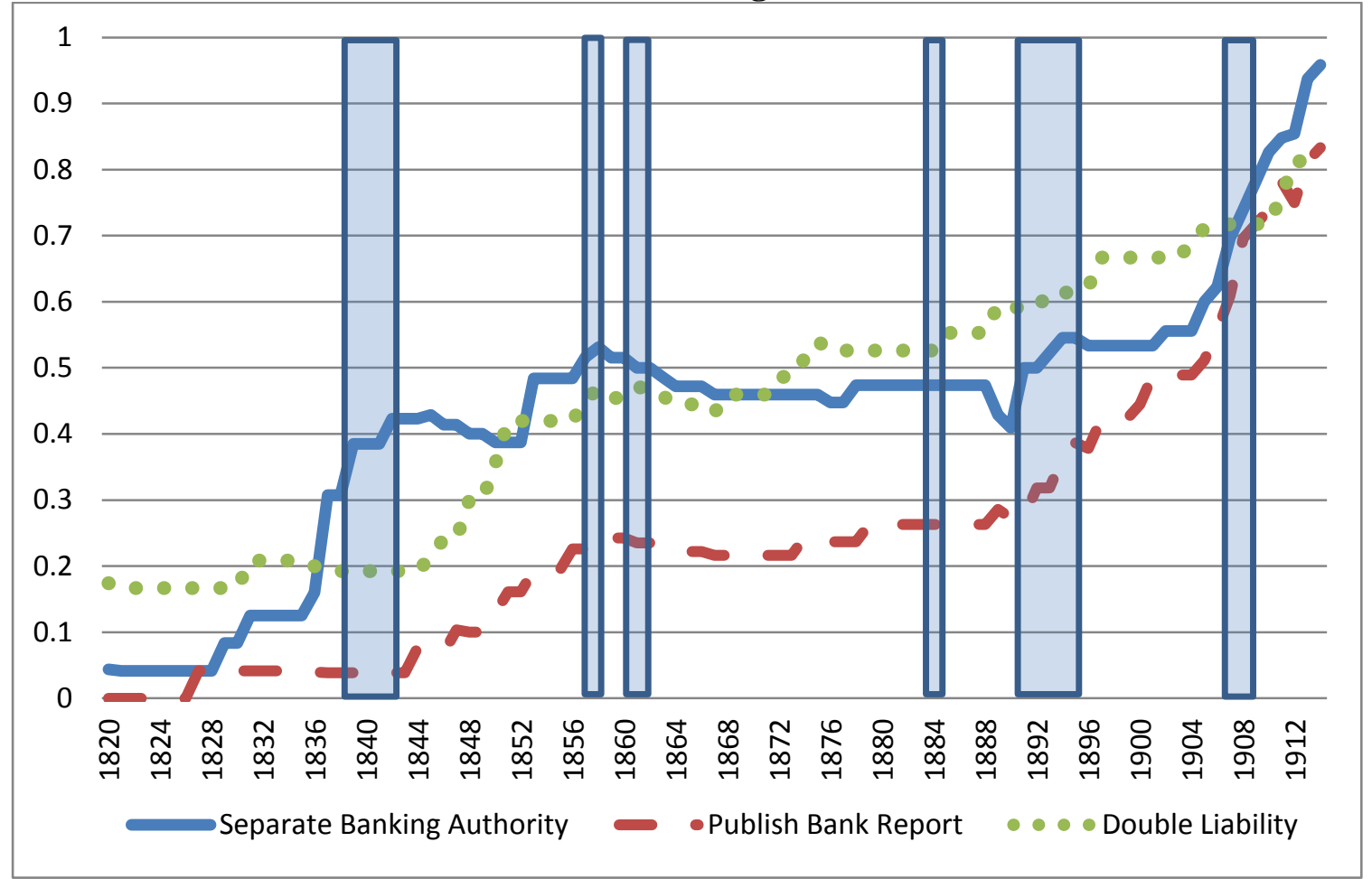

Notes: See the data appendix for sources. Shaded areas mark the three major banking panics (1837/1839, 1890/1893, and 1907) as well as three lesser ones (1857, 1860/1861, and 1884). Since territories did not install regulation and supervision prior to statehood, the creation of new states thus results in reductions in adoption rates. 
Figure 5: Quality of State Bank Supervision in 1911

Panel A: Total Expenses Spent on Bank Supervision (dollars)

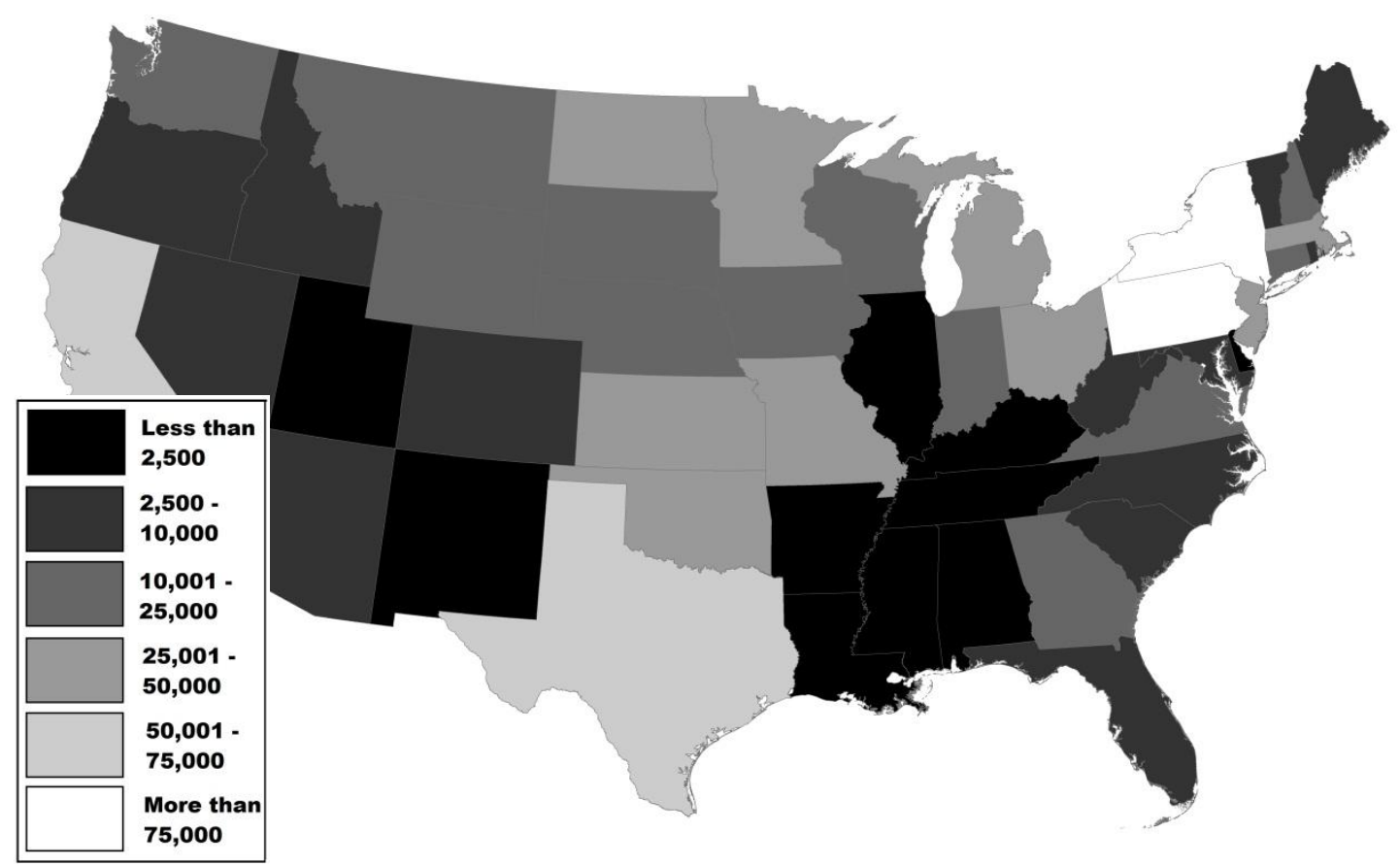

Panel B: Number of Bank Examiners

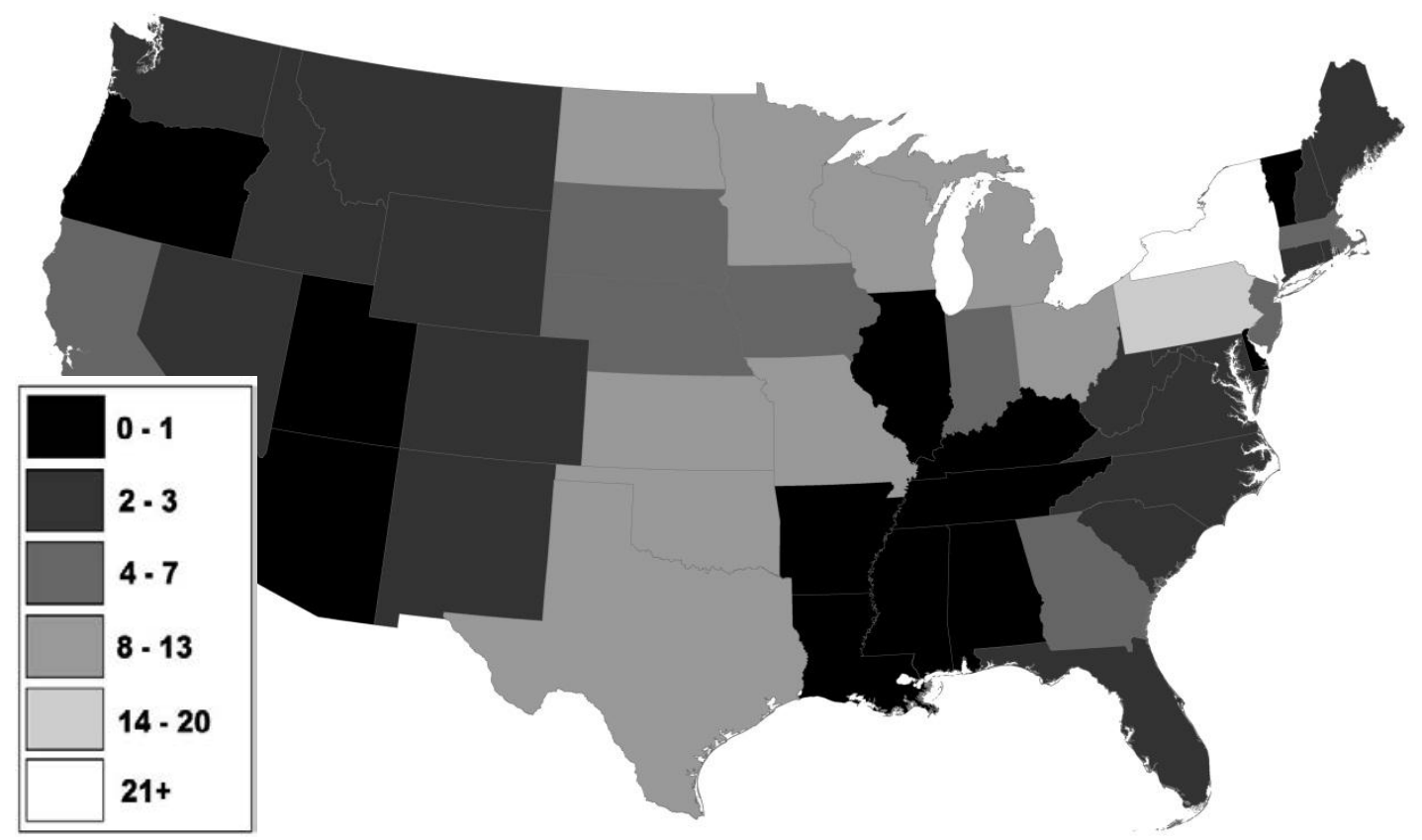

Notes: See the data appendix for sources. The Comptroller's report, on which the figure is based, does not include data for Alabama, Illinois, and Louisiana. 
Table 1: Explaining the Adoption of an Independent State Banking Authority, 1820-1910

\begin{tabular}{|c|c|c|c|}
\hline & $1820-1860$ & 1870-1910 & $1820-1910$ \\
\hline Rate of State Bank Closures & $\begin{array}{c}(1) \\
2.944^{*} \\
{[1.531]}\end{array}$ & $\begin{array}{c}(2) \\
8.932 * \\
{[5.282]}\end{array}$ & $\begin{array}{c}(3) \\
2.275^{* *} \\
{[1.119]}\end{array}$ \\
\hline Rate of National Bank Closures & & $\begin{array}{c}0.026 \\
{[3.440]}\end{array}$ & $\begin{array}{c}-0.806 \\
{[2.607]}\end{array}$ \\
\hline Rate of State Bank Entries & $\begin{array}{c}0.008 \\
{[0.015]}\end{array}$ & $\begin{array}{c}-0.001 \\
{[0.017]}\end{array}$ & $\begin{array}{l}0.018 * * \\
{[0.008]}\end{array}$ \\
\hline Rate of National Bank Entries & & $\begin{array}{c}0.089 \\
{[0.107]}\end{array}$ & $\begin{array}{l}0.160 * * \\
{[0.076]}\end{array}$ \\
\hline Ln(Deposits/Circulation) & $\begin{array}{l}-2.164 \\
{[2.885]}\end{array}$ & $\begin{array}{l}3.337^{* *} \\
{[1.451]}\end{array}$ & $\begin{array}{c}0.963 \\
{[0.672]}\end{array}$ \\
\hline Double Liability & $\begin{array}{l}2.672^{* *} \\
{[1.069]}\end{array}$ & $\begin{array}{c}3.929 * * * \\
{[1.263]}\end{array}$ & $\begin{array}{c}2.798 * * * \\
{[0.661]}\end{array}$ \\
\hline Free Banking State & $\begin{array}{c}-3.386 \\
{[2.532]}\end{array}$ & $\begin{array}{l}-1.240 \\
{[0.882]}\end{array}$ & $\begin{array}{c}-3.024^{* *} \\
{[1.203]}\end{array}$ \\
\hline \# of State Banks Per Capita & $\begin{array}{c}0.209 \\
{[0.174]}\end{array}$ & $\begin{array}{c}-0.023 \\
{[0.079]}\end{array}$ & $\begin{array}{c}-0.027 \\
{[0.049]}\end{array}$ \\
\hline \# of State Banks Per Capita^2 & $\begin{array}{c}-0.004 \\
{[0.002]}\end{array}$ & $\begin{array}{c}0.001 \\
{[0.001]}\end{array}$ & $\begin{array}{c}-0.001 \\
{[0.001]}\end{array}$ \\
\hline Log of State Population (lagged) & $\begin{array}{c}-0.251 \\
{[0.606]}\end{array}$ & $\begin{array}{c}-0.204 \\
{[0.344]}\end{array}$ & $\begin{array}{c}-0.211 \\
{[0.368]}\end{array}$ \\
\hline Percent Urban (lagged) & $\begin{array}{c}2.564 \\
{[9.150]}\end{array}$ & $\begin{array}{l}-2.250 \\
{[2.363]}\end{array}$ & $\begin{array}{c}0.130 \\
{[1.416]}\end{array}$ \\
\hline Percent Black (lagged) & $\begin{array}{l}10.469^{*} \\
{[5.668]}\end{array}$ & $\begin{array}{c}-3.738^{* * *} \\
{[1.377]}\end{array}$ & $\begin{array}{l}-3.640^{*} \\
{[2.000]}\end{array}$ \\
\hline Clearinghouse in State & & & $\begin{array}{c}0.389 \\
{[1.316]}\end{array}$ \\
\hline Year Fixed Effects? & Yes & Yes & Yes \\
\hline Region Fixed Effects? & Yes & Yes & Yes \\
\hline Observations & 85 & 109 & 194 \\
\hline R-squared & 0.363 & 0.364 & 0.315 \\
\hline
\end{tabular}

Notes: Estimates are based on cox proportional hazard model, where the dependent variable is a dummy denoting whether the state had created a state banking department in that decade. Observations are defined at the state-decade level. We drop observations for states that did not yet have commercial banks. Region fixed effects are included in all specifications. Robust standard errors appear in brackets beneath the coefficients. $*, * *$, and $* * *$ denote statistical significance at ten-percent, five-percent, and one-percent levels, respectively. 
Table 2: Explaining the Publishing of Banking Reports, 1820-1910

\begin{tabular}{lc}
\hline & $\mathbf{1 8 2 0 - 1 9 1 0}$ \\
\cline { 2 - 2 } Rate of State Bank Closures & 3.405 \\
Rate of National Bank Closures & {$[2.358]$} \\
& $5.614^{*}$ \\
Rate of State Bank Entries & {$[3.279]$} \\
Rate of National Bank Entries & 0.023 \\
& {$[0.020]$} \\
Ln(Deposits/Circulation) & $0.166^{* *}$ \\
& {$[0.073]$} \\
Separate Bank Authority & $1.813^{*}$ \\
& {$[1.034]$} \\
Double Liability & $2.193^{* * *}$ \\
Free Banking State & {$[0.841]$} \\
\# of State Banks Per Capita & $0.991^{*}$ \\
\# of State Banks Per Capita`2 & {$[0.598]$} \\
Log of State Population (lagged) & -1.759 \\
Percent Urban (lagged) & {$[1.268]$} \\
Percent Black (lagged) & 0.041 \\
Yearinghouse in State & {$[0.082]$} \\
Region Fixed Effects? & -0.001 \\
& {$[0.001]$} \\
& 0.026 \\
& {$[0.443]$} \\
& -1.673 \\
& {$[1.769]$} \\
& $-5.185^{* *}$ \\
& {$[2.313]$} \\
& -0.325 \\
& {$[1.006]$} \\
Yes & Yes \\
& 250 \\
& 0.464 \\
\hline
\end{tabular}

Notes: Estimates are based on Cox Proportional Hazard Model, where the dependent variable is a dummy denoting whether the state began publishing a independent banking report in that decade. Observations are defined at the state-decade level. We drop observations for states that did not yet have commercial banks. Robust standard errors appear in brackets beneath the coefficients. ${ }^{*}, *$, and $* * *$ denote statistical significance at ten percent, five percent, and one percent levels, respectively 
Table 3: Explaining the Level of Bank Supervision in 1911

\begin{tabular}{|c|c|c|c|c|c|c|c|c|c|c|}
\hline \multirow{3}{*}{$\begin{array}{l}\text { Separate Banking Authority } \\
\text { in } 1910\end{array}$} & \multicolumn{4}{|c|}{ Ln(Supervision Expenses) } & \multicolumn{4}{|c|}{ Ln(Examinations in Year) } & \multirow{2}{*}{\multicolumn{2}{|c|}{ \# of Bank Examiners }} \\
\hline & \multicolumn{2}{|c|}{ Total } & \multicolumn{2}{|c|}{ Per State Bank } & \multicolumn{2}{|c|}{ Total } & \multicolumn{2}{|c|}{ Per State Bank } & & \\
\hline & $\begin{array}{c}(1) \\
4.659^{* * *} \\
{[1.143]}\end{array}$ & (2) & $\begin{array}{c}(3) \\
1.707 * * * \\
{[0.448]}\end{array}$ & (4) & $\begin{array}{c}(5) \\
2.617 * * * \\
{[0.878]}\end{array}$ & (6) & $\begin{array}{c}(7) \\
0.243 \\
{[0.184]}\end{array}$ & $(8)$ & $\begin{array}{c}(9) \\
0.624 \\
{[1.224]}\end{array}$ & $(10)$ \\
\hline Double Liability in 1910 & $\begin{array}{c}1.070 \\
{[0.646]}\end{array}$ & & $\begin{array}{c}0.300 \\
{[0.300]}\end{array}$ & & $\begin{array}{l}1.264^{* *} \\
{[0.506]}\end{array}$ & & $\begin{array}{c}0.265^{* *} \\
{[0.121]}\end{array}$ & & $\begin{array}{c}1.759 \\
{[1.699]}\end{array}$ & \\
\hline $\begin{array}{l}\text { Years with Separate Banking } \\
\text { Authority }\end{array}$ & & $\begin{array}{c}0.034 * * \\
{[0.014]}\end{array}$ & & $\begin{array}{c}0.013 * * \\
{[0.006]}\end{array}$ & & $\begin{array}{c}0.017 \\
{[0.010]}\end{array}$ & & $\begin{array}{c}0.001 \\
{[0.002]}\end{array}$ & & $\begin{array}{c}0.010 \\
{[0.018]}\end{array}$ \\
\hline Years with Double Liability & & $\begin{array}{l}0.017^{*} \\
{[0.010]}\end{array}$ & & $\begin{array}{c}0.006 \\
{[0.004]}\end{array}$ & & $\begin{array}{c}0.016^{* *} \\
{[0.007]}\end{array}$ & & $\begin{array}{c}0.003 \\
{[0.002]}\end{array}$ & & $\begin{array}{c}0.028 \\
{[0.021]}\end{array}$ \\
\hline $\begin{array}{l}\text { \# of State Banks Per Capita } \\
\quad \text { in } 1910\end{array}$ & $\begin{array}{l}-0.045 \\
{[0.033]}\end{array}$ & $\begin{array}{l}-0.027 \\
{[0.043]}\end{array}$ & $\begin{array}{c}-0.031 * * \\
{[0.014]}\end{array}$ & $\begin{array}{l}-0.025 \\
{[0.018]}\end{array}$ & $\begin{array}{c}0.007 \\
{[0.027]}\end{array}$ & $\begin{array}{c}0.021 \\
{[0.037]}\end{array}$ & $\begin{array}{c}-0.001 \\
{[0.008]}\end{array}$ & $\begin{array}{c}0.002 \\
{[0.009]}\end{array}$ & $\begin{array}{c}-0.084 \\
{[0.060]}\end{array}$ & $\begin{array}{l}-0.066 \\
{[0.061]}\end{array}$ \\
\hline $\begin{array}{l}\text { \# of National Banks Per } \\
\text { Capita in } 1910\end{array}$ & $\begin{array}{c}0.260 * * \\
{[0.102]}\end{array}$ & $\begin{array}{c}0.387 * * \\
{[0.156]}\end{array}$ & $\begin{array}{c}0.153 * * * \\
{[0.046]}\end{array}$ & $\begin{array}{c}0.198 * * * \\
{[0.063]}\end{array}$ & $\begin{array}{c}0.082 \\
{[0.085]}\end{array}$ & $\begin{array}{c}0.168 \\
{[0.125]}\end{array}$ & $\begin{array}{c}0.023 \\
{[0.027]}\end{array}$ & $\begin{array}{c}0.033 \\
{[0.031]}\end{array}$ & $\begin{array}{c}0.578 * * * \\
{[0.196]}\end{array}$ & $\begin{array}{c}0.636^{* * *} \\
{[0.205]}\end{array}$ \\
\hline $\begin{array}{l}\mathrm{Ln}(\text { Deposits/Circulation }) \\
\quad \text { in } 1910\end{array}$ & $\begin{array}{c}0.609 \\
{[1.019]}\end{array}$ & $\begin{array}{c}0.652 \\
{[1.232]}\end{array}$ & $\begin{array}{c}0.383 \\
{[0.456]}\end{array}$ & $\begin{array}{c}0.398 \\
{[0.519]}\end{array}$ & $\begin{array}{c}0.246 \\
{[0.880]}\end{array}$ & $\begin{array}{c}0.264 \\
{[1.057]}\end{array}$ & $\begin{array}{c}0.094 \\
{[0.235]}\end{array}$ & $\begin{array}{c}0.092 \\
{[0.252]}\end{array}$ & $\begin{array}{l}5.797 * * \\
{[2.806]}\end{array}$ & $\begin{array}{l}5.756^{*} \\
{[2.836]}\end{array}$ \\
\hline Free Banking State & $\begin{array}{c}0.254 \\
{[0.815]}\end{array}$ & $\begin{array}{l}-0.052 \\
{[0.727]}\end{array}$ & $\begin{array}{c}0.411 \\
{[0.401]}\end{array}$ & $\begin{array}{c}0.294 \\
{[0.374]}\end{array}$ & $\begin{array}{c}0.488 \\
{[0.725]}\end{array}$ & $\begin{array}{c}0.336 \\
{[0.768]}\end{array}$ & $\begin{array}{c}0.131 \\
{[0.240]}\end{array}$ & $\begin{array}{c}0.122 \\
{[0.243]}\end{array}$ & $\begin{array}{l}-0.181 \\
{[2.334]}\end{array}$ & $\begin{array}{l}-0.193 \\
{[2.310]}\end{array}$ \\
\hline $\begin{array}{l}\text { Log of Total Population } \\
\quad \text { in } 1910\end{array}$ & $\begin{array}{c}0.184 \\
{[0.330]}\end{array}$ & $\begin{array}{c}0.665^{*} \\
{[0.348]}\end{array}$ & $\begin{array}{l}-0.311^{*} \\
{[0.169]}\end{array}$ & $\begin{array}{l}-0.154 \\
{[0.195]}\end{array}$ & $\begin{array}{c}0.822 * * * \\
{[0.292]}\end{array}$ & $\begin{array}{c}1.222 * * * \\
{[0.407]}\end{array}$ & $\begin{array}{c}0.062 \\
{[0.117]}\end{array}$ & $\begin{array}{c}0.128 \\
{[0.132]}\end{array}$ & $\begin{array}{c}4.004 * * * \\
{[1.205]}\end{array}$ & $\begin{array}{c}4.367 * * * \\
{[1.347]}\end{array}$ \\
\hline Percent Urban in 1910 & $\begin{array}{c}6.371 * * * \\
{[2.025]}\end{array}$ & $\begin{array}{l}5.511 * * \\
{[2.275]}\end{array}$ & $\begin{array}{c}3.811 * * * \\
{[1.082]}\end{array}$ & $\begin{array}{c}3.522 * * * \\
{[1.123]}\end{array}$ & $\begin{array}{c}2.019 \\
{[1.895]}\end{array}$ & $\begin{array}{c}1.339 \\
{[2.416]}\end{array}$ & $\begin{array}{c}0.558 \\
{[0.647]}\end{array}$ & $\begin{array}{c}0.459 \\
{[0.717]}\end{array}$ & $\begin{array}{c}3.602 \\
{[6.312]}\end{array}$ & $\begin{array}{c}3.023 \\
{[5.913]}\end{array}$ \\
\hline Percent Black in 1910 & $\begin{array}{c}5.574 \\
{[4.057]}\end{array}$ & $\begin{array}{c}5.562 \\
{[8.043]}\end{array}$ & $\begin{array}{c}2.849 \\
{[1.697]}\end{array}$ & $\begin{array}{c}2.870 \\
{[3.055]}\end{array}$ & $\begin{array}{c}3.773 \\
{[3.168]}\end{array}$ & $\begin{array}{c}3.483 \\
{[5.527]}\end{array}$ & $\begin{array}{c}0.781 \\
{[0.603]}\end{array}$ & $\begin{array}{c}0.699 \\
{[0.850]}\end{array}$ & $\begin{array}{c}5.807 \\
{[4.327]}\end{array}$ & $\begin{array}{c}4.860 \\
{[4.637]}\end{array}$ \\
\hline $\begin{array}{l}\text { Clearinghouse in State } \\
\quad \text { in } 1910 \\
\text { Region Fixed Effects? } \\
\text { Observations } \\
\text { R-squared }\end{array}$ & $\begin{array}{c}-2.568^{*} \\
{[1.405]} \\
\text { Yes } \\
45 \\
0.784\end{array}$ & $\begin{array}{c}0.287 \\
{[0.995]} \\
\text { Yes } \\
45 \\
0.543\end{array}$ & $\begin{array}{c}-0.878 \\
{[0.653]} \\
\text { Yes } \\
45 \\
0.820\end{array}$ & $\begin{array}{l}0.163 \\
{[0.552]} \\
\text { Yes } \\
45 \\
0.707 \\
\end{array}$ & $\begin{array}{l}-0.358 \\
{[1.560]} \\
\text { Yes } \\
45 \\
0.730\end{array}$ & $\begin{array}{l}1.257 \\
{[1.101]} \\
\text { Yes } \\
45 \\
0.572\end{array}$ & $\begin{array}{c}0.176 \\
{[0.384]} \\
\text { Yes } \\
45 \\
0.464\end{array}$ & $\begin{array}{c}0.328 \\
{[0.319]} \\
\text { Yes } \\
45 \\
0.389\end{array}$ & $\begin{array}{l}-2.262 \\
{[3.251]} \\
\text { Yes } \\
45 \\
0.669\end{array}$ & $\begin{array}{l}-1.938 \\
{[3.308]} \\
\text { Yes } \\
45 \\
0.671\end{array}$ \\
\hline
\end{tabular}

Notes: Estimates are based on OLS regressions, where the dependent variables are listed in the column heading. Observations are defined at the state level. Region fixed effects are included in all specifications. Robust standard errors appear in brackets beneath the coefficients. Alabama, Illinois, and Louisiana are not included in the sample because the Comptroller did not report data on their supervisory practices. *, **, and *** denote statistical significance at ten percent, five percent, and one percent levels, respectively. 
Table A1: Source of First Separate Banking Entity

\begin{tabular}{|c|c|}
\hline State & Source of Separate Banking Entity \\
\hline Alabama & Cited in AL 1911 Report, confirmed in state historical documents \\
\hline Arizona & Cited in AZ 1917 Report, confirmed in state historical documents \\
\hline Arkansas & Cited in AR 1914 Report, confirmed in state historical documents \\
\hline California & Cited in CA 1879 Report, confirmed in state historical documents \\
\hline Colorado & Cited in CO 1907 Report \\
\hline Connecticut & Gruchy (1937) and Dewey \\
\hline Delaware & State historical documents \\
\hline Florida & State historical documents \\
\hline Georgia & Gruchy (1937) \\
\hline Idaho & Cited ID 1905 Report, confirmed in state historical documents \\
\hline Illinois & Gruchy (1937) \\
\hline Indiana & State historical documents \\
\hline Iowa & Gruchy (1937) \\
\hline Kansas & Cited KS 1892 Report, confirmed in state historical documents \\
\hline Kentucky & Cited KY 1913 Report, confirmed in state historical documents \\
\hline Louisiana & Gruchy (1937) \\
\hline Maine & Gruchy (1937) \\
\hline Maryland & State historical documents \\
\hline Massachusetts & Gruchy (1937) \\
\hline Michigan & Gruchy (1937) \\
\hline Minnesota & Weldon (1910) \\
\hline Mississippi & State historical documents \\
\hline Missouri & Modern Department's Website \\
\hline Montana & Year of Earliest Report of State Auditor \\
\hline Nebraska & Year of Earliest Report of State Banking Board \\
\hline Nevada & Cited in NV 1909 Report \\
\hline New Hampshire & Gruchy (1937) \\
\hline New Jersey & Surveys of Banking depart. And related docs. \\
\hline New Mexico & Cited in NM 1915 Report \\
\hline New York & Gruchy (1937) \\
\hline North Carolina & State historical documents \\
\hline North Dakota & Public Examiner made superintendent of banking system. Cited in ND 1890 Report. \\
\hline Ohio & Gruchy (1937) \\
\hline Oklahoma & Oklahoma Historical Society Encyclopedia \\
\hline Oregon & State historical documents \\
\hline Pennsylvania & Cited in PA 1892 Report, Surveys of Banking depart. And related docs. \\
\hline Rhode Island & Gruchy (1937) \\
\hline South Carolina & Weldon (1910) \\
\hline South Dakota & Weldon (1910) \\
\hline Tennessee & Campbel $(1932$, p. 46) \\
\hline Texas & Cited in TX 1911, confirmed in state historical documents \\
\hline Utah & Cited in UT 2013 Report \\
\hline Vermont & Gruchy (1937) \\
\hline Virginia & Cited in VA 1910 Report \\
\hline Washington & Cited in WA 1907 report \\
\hline West Virginia & State historical documents \\
\hline Wisconsin & State historical documents \\
\hline Wyoming & No separate banking department found through 1920 \\
\hline
\end{tabular}

Notes: See the appendix for further details. 
Table A2: Source of Separate Banking Report

\begin{tabular}{|c|c|}
\hline State & Source of Separate Banking Report \\
\hline Alabama & Published first report \\
\hline Arizona & Published first report \\
\hline Arkansas & Published first report \\
\hline California & Published first report \\
\hline Colorado & Published first report \\
\hline Connecticut & Worldcat \\
\hline Delaware & Published first report \\
\hline Florida & No separate publication through 1914 \\
\hline Georgia & Published first report \\
\hline Idaho & Information obtained from $2^{\text {nd }}$ Annual Report of 1906 \\
\hline Illinois & Published first report \\
\hline Indiana & No separate publication through 1914 \\
\hline Iowa & Not separate publication through 1914 \\
\hline Kansas & Information obtained from $2^{\text {nd }}$ Annual Report of 1894 \\
\hline Kentucky & Published first report \\
\hline Louisiana & Published first report \\
\hline Maine & Information obtained from $19^{\text {th }}$ Annual Report of 1875 \\
\hline Maryland & Published first report \\
\hline Massachusetts & Published first report \\
\hline Michigan & Published first report. State Treasurer before 1889. \\
\hline Minnesota & Published first report. Public Examiner before 1910. \\
\hline Mississippi & Published first report \\
\hline Missouri & Information obtained from 1899 Annual Report \\
\hline Montana & Information obtained from $12^{\text {th }}$ Annual Report in 1906. \\
\hline Nebraska & Worldcat \\
\hline Nevada & Published first report \\
\hline New Hampshire & Worldcat \\
\hline New Jersey & Worldcat \\
\hline New Mexico & Published first report \\
\hline New York & Bodenhorn $(2003,216)$ \\
\hline North Carolina & Published first report \\
\hline North Dakota & Information obtained from $3^{\text {rd }}$ Annual Report of 1892. \\
\hline Ohio & Published first report. Auditor of State Before 1908. \\
\hline Oklahoma & Information obtained from $5^{\text {th }}$ Biennial Annual Report of 1906 \\
\hline Oregon & Published first report \\
\hline Pennsylvania & First surviving record in 1827 . First report could be earlier. \\
\hline Rhode Island & Information obtained from 1863Annual Report \\
\hline South Carolina & Published first report \\
\hline South Dakota & Information obtained from $3^{\text {rd }}$ Biennial Report of 1898 \\
\hline Tennessee & No banking data published periodically or separately through 1914 \\
\hline Texas & Published first report \\
\hline Utah & Worldcat \\
\hline Vermont & Information obtained from 1877-78 Annual Report \\
\hline Virginia & Published first report \\
\hline Washington & Published first report \\
\hline West Virginia & Information obtained from $2^{\text {nd }}$ Annual Report of 1902. State Auditor before 1901. \\
\hline Wisconsin & Published first report \\
\hline Wyoming & No banking data published periodically or separately through 1914 \\
\hline
\end{tabular}
Notes: See the appendix for further details. 